\title{
IRE1- and HAC1-independent transcriptional regulation in the unfolded protein response of yeast
}

\author{
Martin Schröder, ${ }^{1}$ Robert Clark ${ }^{1}$ and \\ Randal J. Kaufman ${ }^{1,2 *}$ \\ ${ }^{1}$ Howard Hughes Medical Institute and ${ }^{2}$ Department of \\ Biological Chemistry, University of Michigan Medical \\ Center, Ann Arbor, MI, USA.
}

\section{Summary}

The unfolded protein response (UPR) is a signalling pathway leading to transcriptional activation of genes that protect cells from accumulation of unfolded proteins in the lumen of the endoplasmic reticulum (ER). In yeast, the only known ER stress signalling pathway originates at the type I transmembrane protein kinase/ endoribonuclease Ire1p. Ire1p regulates synthesis of the basic leucine-zipper (bZIP)-containing transcription factor Hac1p by controlling splicing of HAC1 mRNA. Only spliced HAC1 mRNA (HAC1') is translated, and Hac1'p activates transcription of genes that contain a conserved UPR element (UPRE) in their promoters. Here, we demonstrate that in addition to this well-understood ER stress signalling pathway, a second, IRE1, HAC1 and UPRE-independent mechanism for transcriptional activation upon ER stress, exists in yeast. A genetic screen identified recessive SIN4 alleles as suppressors of a defective UPR in ire1 $\Delta$ strains. Elevation of basal transcription in $\sin 4$ strains or by tethering the RNA polymerase II holoenzyme with LexAp-holoenzyme component fusion proteins to a promoter allowed for activation of the promoter by ER stress in an IRE1, HAC1 and UPREindependent manner. We propose that this novel second ER-to-nucleus signal transduction pathway culminates in core promoter activation (CPA) through stimulation of RNA polymerase II holoenzyme activity. Core promoter activation was observed upon diverse cellular stresses, suggesting it represents a primordial stress-induced gene activation mechanism.

\section{Introduction}

All eukaryotic cells deal with the accumulation of unfolded proteins in the ER by mounting protective

Accepted 8 April, 2003. *For correspondence. E-mail kaufmanr@umich.edu; Tel. (+1) 734763 9037; Fax (+1) 734763 9323.

(C) 2003 Blackwell Publishing Ltd responses, including the induction of ER-resident molecular chaperones and upregulation of ER-associated protein degradation. In higher eukaryotes, at least three signalling pathways contribute to the UPR (Shen et al., 2001). First, the type I transmembrane kinase/endoribonuclease Ire1p is activated by release of BiP/GRP78/ KAR2 from its lumenal domain upon accumulation of unfolded proteins in the ER lumen (Bertolotti et al., 2000). Activated Ire1p initiates spliceosome-independent RNA splicing of mRNAs encoding the bZIP transcription factors HAC1 in yeast (Sidrauski and Walter, 1997) and XBP-1 in higher eukaryotes (Shen et al., 2001; Yoshida et al., 2001; Calfon et al., 2002). Second, the eukaryotic initiation factor $2 \alpha$ (elF2 $\alpha$ ) kinase PERK, that shares a functional ER lumenal domain with Ire1p (Liu et al., 2000), attenuates translation by phosphorylation and inactivation of elF $2 \alpha$. This translational control event contributes to transcriptional activation of ER chaperone genes (Scheuner et al., 2001). Third, the transmembrane protein ATF6, residing in the ER membrane, is transported to the Golgi complex and its cytoplasmic domain released by proteolysis by S1P and S2P (Ye et al., 2000). The cytoplasmic portion of cleaved ATF6 translocates to the nucleus and activates transcription of target genes (Haze et al., 1999; Wang et al., 2000). Common to these three pathways is the transcriptional induction of a set of genes.

Yeast lacks both ATF6 and PERK. Thus, the only known UPR pathway in this organism is the one originating at Ire1p. Activated Ire1p cleaves the mRNA for the bZIP transcription factor $H A C 1$ at the 5 '- and 3 '-exon/intron junctions (Sidrauski and Walter, 1997) and both exons are then joined by tRNA ligase (Sidrauski et al., 1996). This unconventional splicing reaction results in the removal of a translational attenuator residing in the intron of $H A C 1$ mRNA and allows for regulated synthesis of Hac1p only during periods of ER stress (Chapman and Walter, 1997). Hac1p derived from spliced HAC1 mRNA is a more potent transcriptional activator than Hac1p derived from unspliced HAC1 mRNA (Mori et al., 2000). Hac1p activates transcription of genes containing a conserved UPR element (UPRE) in their promoters as a homodimer (Mori et al., 1998). However, about one-third of the UPRE promoter activation is independent of IRE1 and HAC1 (Shamu and Walter, 1996) and a genome-wide analysis identified 87 open reading frames (ORF) that are induced 
in response to ER stress in ire $1 \Delta$ and hac1 $1 \Delta$ strains (Travers et al., 2000).

Here, we demonstrate the existence of additional, IRE1and $H A C 1$-independent, ER stress response pathways in yeast. These pathways were revealed by elevation of basal transcription. Either sin4 mutations or recruitment of a LexAp-RNA polymerase II holoenzyme fusion protein to a lacZ reporter with LexA-binding sites, but no UPRE, increased basal transcription. Induction of transcription in response to ER stress in these two systems was two- to threefold and independent of any component of the classic UPR, that is IRE1, HAC1 or the UPRE. We conclude that an IRE1- and HAC1-independent pathway for transcriptional activation exists in yeast and propose that this pathway culminates in stimulation of the activity of a core promoter, a process we term core promoter activation (CPA). Our data are consistent with stimulation of RNA polymerase II holoenzyme activity by ER stress as a possible mechanism for CPA. In addition, CPA was also observed when other physiological stresses were induced. These findings significantly contribute to our understanding of IRE1- and HAC1-independent promoter activation in response to ER stress.

\section{Results}

\section{Additional ER stress response pathways exist in yeast}

In yeast, the UPR is thought to be exclusively dependent on Ire1p-mediated splicing of HAC1 mRNA. However, colonies of ire $1 \Delta$ and hac1 $1 \Delta$ strains that carry a UPRE-lacZ reporter developed a light blue colour in the presence of tunicamycin on X-Gal plates after prolonged incubation, but not in the absence of tunicamycin (data not shown). In addition, using DNA microarrays, a twofold or stronger induction of 87 ORFs by ER stress did not require IRE1 or HAC1 function (Travers et al., 2000). Finally, about onethird of the activation of promoters containing an UPRE was independent of IRE1 and HAC1 function (Shamu and Walter, 1996). These observations suggest that additional signal transduction pathways from the ER to the nucleus exist in yeast that do not require either IRE1 or HAC1.

\section{Isolation of mutants with an IRE1/ERN1-independent ER to nucleus signalling phenotype}

To identify genes involved in these IRE1-independent ER stress signalling pathways we isolated mutant yeast strains that efficiently signal ER stress in the absence of functional IRE1/ERN1. ire1 $\Delta$ strains were subjected to random mutagenesis with ethyl methanesulfonate. About $1 \times 10^{7}$ mutants were selected for increased resistance to tunicamycin $\left(0.1-0.25 \mu \mathrm{g} \mathrm{ml}^{-1}\right)$. Colonies with increased resistance to tunicamycin were then screened for activation of an integrated UPRE-lacZ reporter [UPRE- $P_{\mathrm{CrC1} 1-178)^{-}}$lacZ, see Experimental procedures for details] in response to ER stress (Fig. 1A). A total of 91 mutant strains activated the reporter in response to ER stress. All strains carried recessive mutations and 84 mutant strains belonged to the same complementation group. This strongly suggested allelism of these mutations. We designate this gene as EIS1 for ERN1 (synonymous to IRE1) independent signalling. However, seven mutants did not fall into this complementation group. These mutants can constitute up to seven additional alleles.

Next we determined the extent of the ER stress response in an ire1 $\Delta$ eis 1-68 strain. We also included one mutant (ire1 $\mathrm{mt}$ no. 82) that did not fall into the major complementation group. Resistance to tunicamycin and 2-deoxy-D-glucose was increased in the ire1 $\Delta$ eis1-68 strain and mutant no. 82 compared with the parental ire1 $\Delta$ strain (Fig. 1B). Because tunicamycin and 2-deoxy-Dglucose induce accumulation of unfolded proteins in the lumen of the ER by different mechanisms (Schwarz et al., 1979; Hubbard and Ivatt, 1981), resistance to both drugs indicates an improved handling of unfolded proteins in the ER lumen in both strains. In addition, both strains showed a rapid two to threefold increase in $\beta$-galactosidase production upon tunicamycin treatment (Fig. 1C). As early as 30 min after the addition of tunicamycin, an increase in $\beta$-galactosidase activity was detectable. This indicated that these strains responded to the presence of unfolded proteins in the ER lumen itself, and not to secondary perturbations of cellular metabolism caused by the accumulation of unfolded proteins. However, we also observed elevated levels of $\beta$-galactosidase expression prior to induction of ER stress (Fig. 1C), which reflects increased basal transcription of the reporter in these strains. In summary, several mutants were isolated that allow for efficient ER-to-nucleus signalling in the absence of functional IRE1.

\section{EIS1 is SIN4}

Based on the large number of mutants that fell into a single complementation group, we reasoned that a single gene mutation is responsible for restoration of ER stress signalling in our eis 1 mutants. The gene encoding the recessive mutation was isolated by complementation with a yeast genomic DNA library. Twenty-eight colonies containing plasmids that complemented induction of the lacZ reporter in response to ER stress were isolated. Resistance to tunicamycin was also reduced by these plasmids. Plasmid DNA was rescued from these strains and five different complementing plasmids were identified by DNA sequencing. One plasmid (Rose-1) was isolated 24 times, whereas the other four were isolated only once. Introduction of 

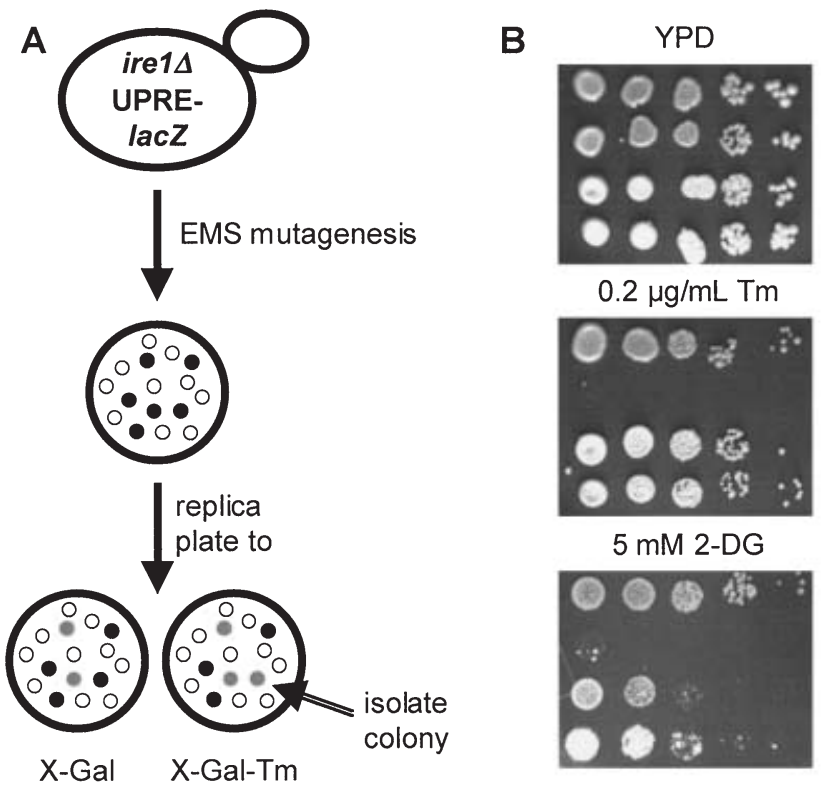

WT

ire14

ire1 $\Delta$ eis $1-68$

ire1 $\mathrm{mt} \# 82$

$0.2 \mu \mathrm{g} / \mathrm{mL} \mathrm{Tm}$

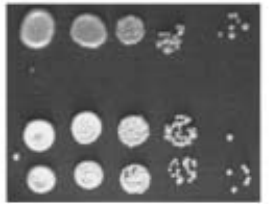

WT

ire1 $1 \Delta$

ire1 $\Delta$ eis1-68

ire1 $\mathrm{mt} \# 82$

$5 \mathrm{mM}$ 2-DG

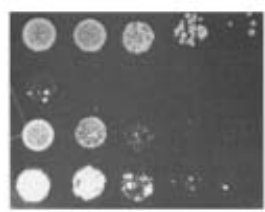

WT

ire1s

ire1 $\Delta$ eis $1-68$

ire1 $\Delta \mathrm{mt} \# 82$
Fig. 1. Characterization of eis (ERN1 independent signalling) mutations.

A. Schematic outline of the genetic screen to isolate eis mutations. An ire1 $1 \Delta$ strain (AWY19 or MSY9-1) was mutagenized with ethyl methanesulfonate (EMS) as described in Experimental procedures. Colonies resistant to $0.25 \mu \mathrm{g} \mathrm{ml}^{-1}$ tunicamycin (Tm; black circles) were screened for induction of an UPRE-lacZ reporter in response to ER stress (grey circles) by replica plating to X-Gal- and X-Gal-Tmplates. Open circles represent colonies sensitive to $0.25 \mu \mathrm{g} \mathrm{ml}^{-1}$ tunicamycin.

B. eis mutants ire $1 \Delta$ eis1-68 and ire $1 \Delta \mathrm{mt} \mathrm{no.}$ 82 are resistant to tunicamycin and 2-deoxy-Dglucose. Serial 10 -fold dilutions of fresh overnight cultures were spotted onto yeast extractpeptone-dextrose (YPD) plates containing $0.2 \mathrm{\mu g} \mathrm{ml}^{-1}$ tunicamycin, $5 \mathrm{mM}$ 2-deoxy-Dglucose (2-DG) and control plates.

C. Induction of an UPRE- $P_{\mathrm{CYC1}(-178)}$-lac $Z$ reporter by ER stress in eis mutants ire1 $1 \Delta$ eis 1 68 and a second mutant (ire $1 \Delta \mathrm{mt} \mathrm{no.} \mathrm{82)} \mathrm{that}$ does not belong to the major complementation group. Cells were grown to mid-log phase and tunicamycin added to $2 \mathrm{\mu g} \mathrm{ml}^{-1}$. Samples were taken before (solid bars), 30 (crossed bars) and 120 min (open bars) after addition of tunicamycin. The average and standard error from four independent protein and $\beta$-galactosidase determinations are shown. In both panels the strains used were: WT (AWY14), ire1A (AWY19).
Rose-1 and Rose-2 (data not shown) into an ire14 eis168 strain reduced both tunicamycin resistance and tunicamycin-induced expression from the UPRE-lacZ reporter construct (Fig. 2A). The DNA inserts common to both plasmids encode two known genes, SIN4 and YTP1, and one putative ORF, YNL235c (Fig. 2A). Thus, it is possible that SIN4, YTP1 or YNL235c are allelic with EIS1. Because the isolated mutations in EIS1 were recessive and therefore most likely loss-of-function alleles, we introduced $\sin 4$ and ytp 1 null alleles into an ire $1 \Delta$ background. The ire $1 \Delta$ $\sin 4 \Delta$ strain displayed tunicamycin resistance and tunicamycin-induced UPRE-lacZ reporter gene expression identical to an ire1 $\Delta$ eis 1-68 strain (Fig. 2A, B). In contrast, the ire $1 \Delta$ ytp $1 \Delta$ strain was neither resistant to tunicamycin nor displayed induction of the UPRE-lacZ reporter. The sin4 deletion leaves about $500 \mathrm{bp}$ of $3^{\prime}$-sequence for ORF YNL235c intact. Therefore we do not expect that expression of YNL235c was affected by this deletion.
Null mutations in SIN4 cause broad alterations in transcription of a large variety of genes. Loss-of-function mutations in SIN4 are associated with a decrease in nucleosome density in the chromatin (Jiang and Stillman, 1992) and changes in transcription of many, but not all, genes (Mizuno and Harashima, 2000). Thus, it is possible that the additional plasmid-borne copy of SIN4 is only a suppressor of induction of UPRE- $P_{C Y C 1(-178)}$-lac $Z$ transcription in response to ER stress, due to altered expression of SIN4 and subsequent Sin4p dosage-dependent effects on chromatin structure. To confirm that SIN4 is indeed the complementing gene and not only a suppressor of the eis1-68 allele, a sin4 null mutation was introduced into an ire1 $\Delta$ strain, and the resulting ire1 $\Delta \sin 4 \Delta$ strain crossed to a representative mutant of the major complementation group (ire1s eis1-13). The resulting

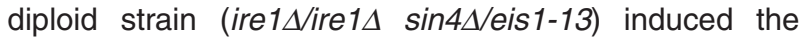
UPRE- $P_{C Y C 1(-178)}$-lac $Z$ reporter in response to ER stress 


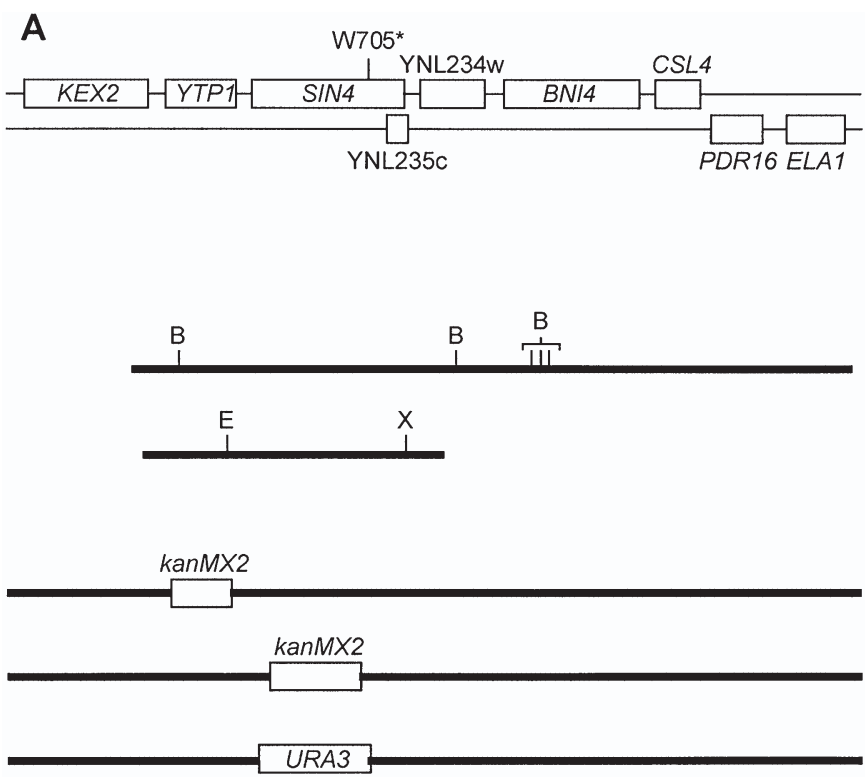

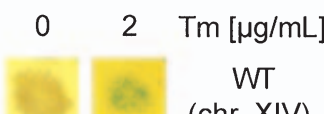

(chr. XIV)

ire1s

ire1 $1 \Delta$

eis1-68

Rose-22

Rose-1

ire1 $1 \Delta$

ytp1s

ire1 $1 \Delta$

$\sin 4 \Delta$

$\sin 4 \Delta:: U R A 3$
B

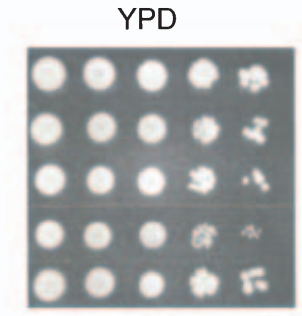

$0.5 \mu \mathrm{g} / \mathrm{mL} \mathrm{Tm}$

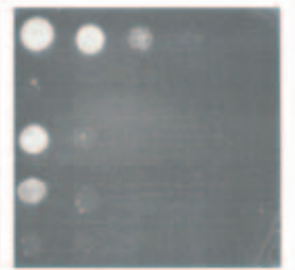

WT

ire1A

ire1 $1 \Delta$ eis 1-68

ire $1 \Delta \sin 4 \Delta$

ire $1 \Delta$ ytp $1 \Delta$

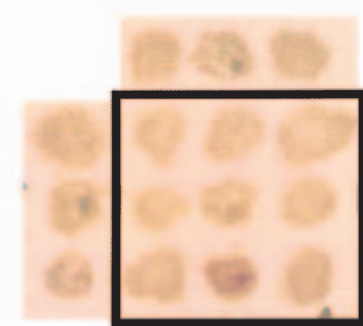

0

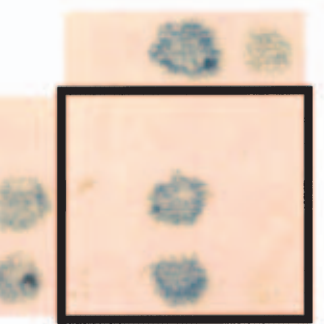

2 ire1 $1 \Delta$

ire $1 \Delta$

eis1-68

ire1 14

$\sin 4 \Delta$

$\operatorname{Tm}[\mu \mathrm{g} / \mathrm{mL}]$

Fig. 2. EIS1 is SIN4.

A. Schematic drawings of the insert in two complementing plasmids (Rose-1 and Rose-22), WT and mutant ytp1 $1:$ kanMX2, sin4 $4:$ kanMX2, and $\sin 4 \triangle:: U R A 3$ loci. The location of the mutation in allele $\sin 4-68$ (W705*, *indicates a stop codon) is also indicated. Shown to the right is the growth phenotype and induction of an UPRE-lacZ reporter in response to ER stress. B: BamHI; E: EcoRI; X: Xbal; Tm: tunicamycin.

B. Resistance of ire1 $1 \Delta \sin 4 \Delta(\mathrm{RCY} 8)$ and ire $1 \Delta$ ytp1 $(\mathrm{RCY} 9)$ strains to tunicamycin. Serial 10-fold dilutions of fresh, overnight cultures were spotted onto YPD plates containing $0.5 \mu \mathrm{g} \mathrm{ml}^{-1}$ tunicamycin and control plates.

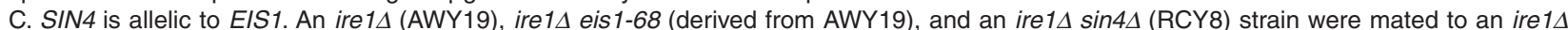
(MSY9-1), and two mutant strains (ire14 eis 1-13, and mt. no. 82) isolated after ethyl methanesulfonate mutagenesis of MSY9-1. Diploid and parental haploid cells were tested for growth and induction of the UPRE-lacZ reporter by replica plating to X-Gal (left) and X-Gal-tunicamycin (right) plates. The phenotype of diploids derived from mating the indicated haploid strains in the corresponding rows and columns is shown inside the box. The phenotype of the parental haploid strain is shown outside the box. The WT strain used in all panels was AWY14.

(Fig. 2C). In contrast, ER stress signalling was not observed when the ire1 $\Delta \sin 4 \Delta$ strain was mated to a mutant strain that did not belong to the major complementation group (ire1 $\Delta \mathrm{mt} \mathrm{no.} \mathrm{82,} \mathrm{Fig.} 2 \mathrm{C}$ ). These data demonstrate that SIN4 is allelic with EIS1 and not a suppressor of eis1 mutations. We conclude that EIS1 is SIN4. We designate the recessive sin4 allele as $\sin 4-68$ (synonymous to eis1-68). 
To identify the mutation in the sin4-68 allele, the sin4-68 allele was cloned into pRS306. The SIN4 ORF was sequenced in both directions, and compared with the published sequence (Chen et al., 1993). Two point mutations were identified, at position +1836 a $G \rightarrow T$ transversion (Glu612Asp), and at position +2114 a $G \rightarrow A$ transition; resulting in a stop codon at amino acid position 705. Because mutagenesis with ethyl methanesulfonate resulted exclusively in transitions (Kohalmi and Kunz, 1988), we reasoned that the transversion at position +1836 is present in the parental strain. To verify this hypothesis, the SIN4 gene from the parental ire1 $\Delta$ strain (AWY19) was cloned, and the relevant region sequenced. Indeed, the $\mathrm{G} \rightarrow \mathrm{T}$ transversion at position +1836 , but not the transition, was present in the parental strain (data not shown). The Glu612Asp-Sin $4 p$ is functional, as no phenotypes related to $\sin 4$ mutations were observed in the parental strain (data not shown). Thus, sin4-68 encodes a C-terminal truncation of $\operatorname{Sin} 4 p$ in which about $28 \%$ of the protein is missing.

\section{Mutations in SIN4 activate transcription in response to ER stress in ire1 $1 \Delta$ strains}

Next, we compared the phenotype of the ire $1 \Delta \sin 4 \Delta$ and the ire1 $\Delta$ sin4-68 strain. Both strains showed a similar elevation of basal transcription from the UPRE-P $\mathrm{CYC1(-178)}^{-}$ lac $Z$ reporter, and showed a similar induction of $\beta$-galactosidase after addition of tunicamycin (Fig. 3A) or DTT (Fig. 3B). DTT unfolds proteins in the ER lumen by reducing intra- and intermolecular disulphide bonds. Resistance to tunicamycin of the ire $1 \Delta \sin 4 \Delta$ strain was also indistinguishable from the ire1 $\Delta$ sin4-68 strain (Fig. 2B). Taken together, these data show that ire1 $\Delta$ sin4-68 and ire1 $\Delta$ $\sin 4 \Delta$ strains have a very similar phenotype and that transcriptional activation of the UPRE-lacZ reporter can be detected reproducibly in ire $1 \Delta \sin 4 \Delta$ strains. Further, basal transcription and induction of the UPRE-P ${ }_{\mathrm{CYC} 1(-178)^{-}}$ lac $Z$ reporter in both the ire $1 \Delta \sin 4 \Delta$ and the ire $1 \Delta$ sin468 strain were indistinguishable from a $\sin 4 \Delta$ strain. This suggests that SIN4, IRE1 and HAC1 act in the same genetic pathway to activate transcription by the IRE1HAC1-pathway.

Sin $4 p$ is part of the mediator complex that regulates activity of the RNA polymerase II holoenzyme and the level of transcription of target promoters. Sin $4 p$ forms a subcomplex with Gal11p and Rgr1p within the mediator that can be dissociated from the other mediator components. RGR1 is an essential gene (Carlson, 1997). gal11 and sin4 mutants often have similar transcriptional defects (Fassler et al., 1991; Jiang and Stillman, 1992; Carlson, 1997). However, both proteins do not play identical roles in transcriptional regulation (Kim et al., 2000). To determine whether restoration of ER
A

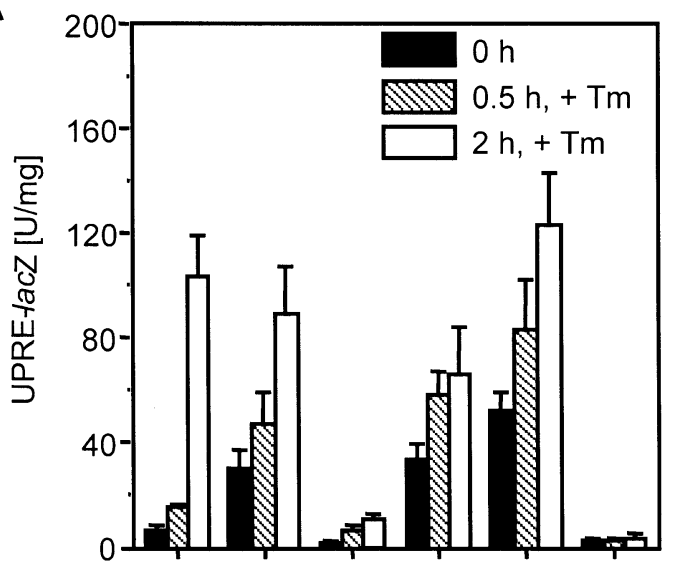

B

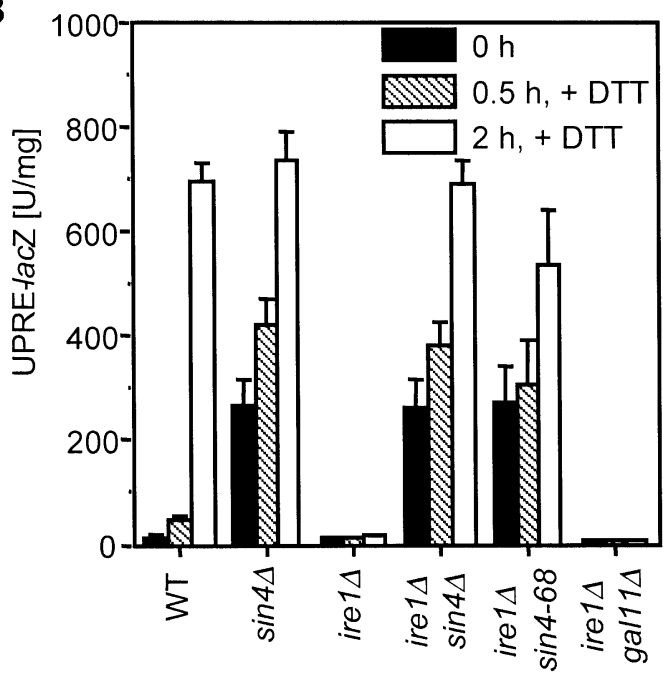

Fig. 3. Basal and stimulation of transcription by ER stress in ire1 $1 \Delta$ $\sin 4 \Delta$ and ire $1 \Delta$ gal11 $\Delta$ mutants. Induction of a lac $Z$ reporter by ER

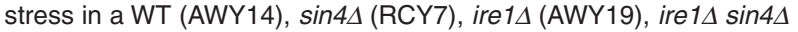
(RCY8), ire14 sin4-68 (AWY19 mt. no. 68) and ire14 gal114 (MSY293-01) strain by treatment of mid-log phase cells with (A) $0.4 \mu \mathrm{g} \mathrm{ml}^{-1}$ tunicamycin (Tm) or (B) $3 \mathrm{mM} \mathrm{DTT}$, for 0.5 (crossed bars) or $2 \mathrm{~h}$ (open bars). Black bars represent untreated samples. The average and standard error from four independent protein and $\beta$-galactosidase determinations are shown.

stress signalling in ire $1 \Delta \sin 4 \Delta$ strains results from a defect in mediator function, an ire1 $\Delta$ gal11 1 double null mutant strain was constructed and analysed. Deletion of GAL11 did not increase basal transcription from the reporter, or induction by ER stress (Fig. 3). This demonstrates that increased transcription by ER stress seen in $\sin 4 \Delta$ strains is specific to selective components of the mediator. Further, the gal11 deletion abolished the two to threefold ER-stress induction seen in ire1 $\Delta$ and ire1 $\Delta$ sin4 $\Delta$ strains (Fig. 3). This observation shows that the increase in $\beta$-galactosidase activity by ER stress in the ire1s strains has a transcriptional basis and is not an artefact that is associated with the IRE1 deletion. 
IRE1 and HAC1 are dispensable for transcriptional induction in response to ER stress in $\sin 4$ mutants

Next we asked whether induction of the UPRE-P $\mathrm{P}_{\mathrm{CYC1}(-178)^{-}}$ lacZ reporter in response to ER stress requires $H A C 1$ function. Hac1p is a bZIP-transcription factor (Nojima et al., 1994) that binds to the conserved UPRE and promotes transcription of target genes, e.g. KAR2 (Mori et al., 1998). Thus, hac1 $\Delta$ strains are defective in activation of the UPR and display a phenotype similar to ire $1 \Delta$ strains (Cox and Walter, 1996). On the other hand, deletion of the UPRE from the lac $Z$ reporter construct should also eliminate Hac1p-dependent transcription of the reporter construct. Therefore, we constructed a series of ire1 $\Delta$, ire1 $\Delta$ $\sin 4 \Delta$ and ire1 $\Delta$ hac1 $\Delta \sin 4 \Delta$ strains with the UPRE-

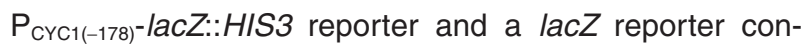
struct without a UPRE (called $P_{\mathrm{CrC1}(-178)}$-lacZ::HIS). All strains displayed a markedly similar behaviour (Fig. 4A). Basal expression of the reporter construct was elevated in all strains. This demonstrates that SIN4 negatively regulates expression of the $P_{\mathrm{CYC1}(-178)}$-lacZ: HIS3 reporter in non-induced cells. More importantly, all strains induced the lacZ reporter after addition of tunicamycin to a similar degree (Fig. 4A) and showed a similar level of resistance to $1 \mathrm{mM}$ 2-deoxy-D-glucose, a concentration that killed the ire1 strain (Fig. 4B). Furthermore, resistance to ER stress is not increased by a sin 4 mutation in an otherwise WT background (data not shown). Taken together, these data show that ER stress signalling in sin4 strains is completely independent of the classic UPR, as it does not require IRE1, HAC1 or the UPRE.

\section{A core promoter is sufficient for activation of transcription by ER stress}

Mutations in SIN4 are associated with a less dense nucleosome packaging of DNA and therefore an increased accessibility of promoters for the transcriptional machinery (Jiang and Stillman, 1992). Increased accessibility of the promoter for RNA polymerase II in $\sin 4 \Delta$ strains may account for the increase in basal transcription of the $P_{\mathrm{CYC1(-178)}}$-lacZ reporter in unstressed cells before induction of ER stress by treating the cells with tunicamycin (Figs 1A, 3 and 4A). However, we also observed an increase in transcription in $\sin 4 \Delta$ strains after induction of ER stress (see for example Fig. 3 and compare the bars before addition of the drug, which correspond to the $0 \mathrm{~h}$ values with those after addition of tunicamycin or DTT). This increase was independent of IRE1, HAC1 or the

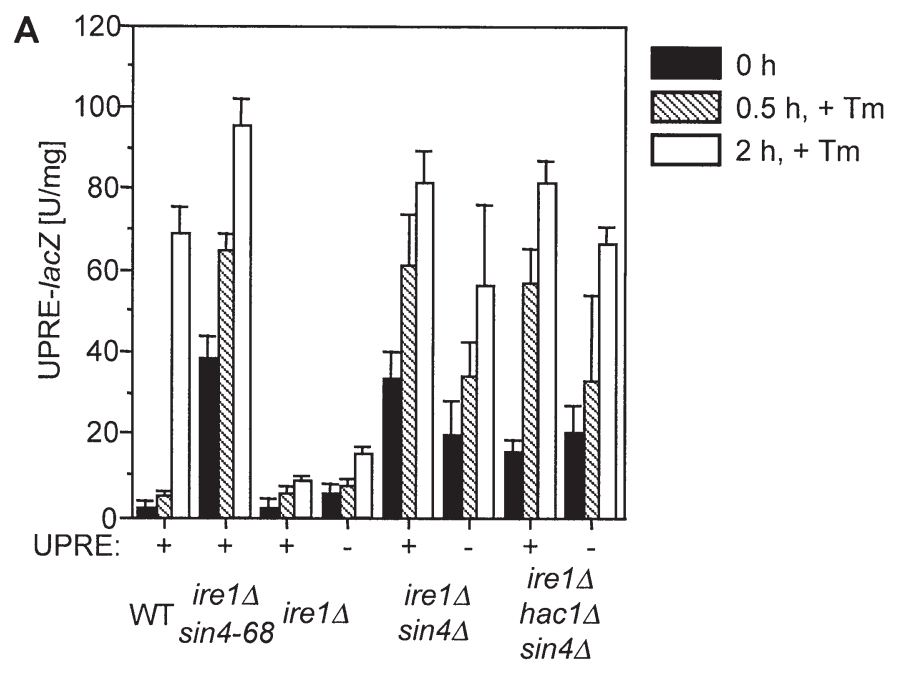

Fig. 4. Components of the UPR are not required for stimulation of transcription by ER stress in $\sin 4$ mutants.

A. Induction of a lac $Z$ reporter by ER stress in WT (AWY14), ire1 1 (RCY1), ire1 $\Delta$ sin4 $\Delta$ (RCY3) and ire1 $\Delta$ hac1 $\Delta$ sin4 4 (RCY5) strains with the UPRE-P $P_{\text {CYC1(-178)-lacZ::HIS3 reporter }}$ and ire1 $\Delta$ (RCY2), ire1 $\Delta \sin 4 \Delta$ (RCY4) and ire 1s hac1 $\Delta$ sin4 $\Delta$ (RCY6) strains with the $P_{\text {CYC1(-178)-lacZ::HIS3 reporter. Cells were }}$

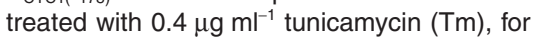
0.5 (crossed bars) or $2 \mathrm{~h}$ (open bars); black bars represent untreated samples. The average and standard error from four independent protein and $\beta$-galactosidase determinations are shown.

B. Resistance of some of the strains used in (A) to $1 \mathrm{mM}$ 2-deoxy-D-glucose (2-DG).

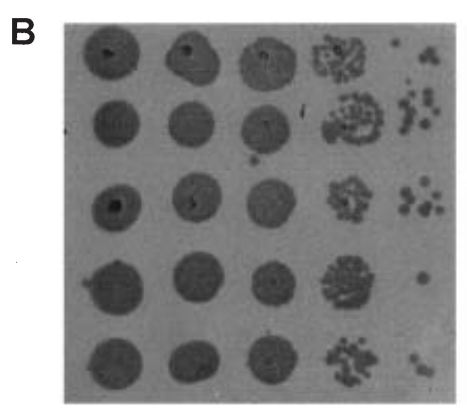

0

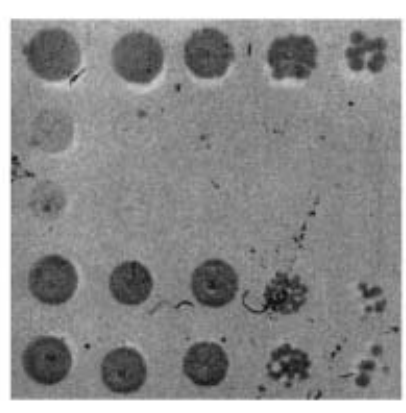

1
WT
ire1 1
ire1
ire1
sin4
ire1 $\Delta$ hac1 1
$\sin 4 \Delta$

2-DG [mM]

(c) 2003 Blackwell Publishing Ltd, Molecular Microbiology, 49, 591-606 
UPRE (Fig. 4). Therefore, we speculated if a core promoter is sufficient to mediate this stimulating effect of ER stress on transcription. To rule out changes in accessibility of the promoter for the holoenzyme by ER stress, the holoenzyme was artificially recruited to a lexA $\mathrm{A}_{\mathrm{op}}-l a c Z$ reporter using fusions of the DNA binding protein LexA to the mediator proteins $\operatorname{Sin} 4 p$ or Srb11p (Kuchin et al., 2000) (Fig. 5A). To eliminate effects of the classic UPR pathway, the experiment was performed in an ire1 $\Delta$ and SIN4 WT background. Expression of either LexA-Sin4p or LexA-Srb11p increased basal transcription of the reporter several hundred fold (Fig. 5B). Addition of tunicamycin (Fig. 5B) or 2-deoxy-D-glucose (10 mM, data not shown) further increased $\beta$-galactosidase activity by 1.5 - to twofold (Fig. 5B). Northern blot analysis (Fig. 5C) confirmed that the increase in $\beta$-galactosidase activity correlated with a 1.5-fold increase in lacZ mRNA (Fig. 5D). Western blot analysis demonstrated that the increase in expression of the lex $\mathrm{A}_{\mathrm{op}}-$ lac $Z$ reporter after induction of ER stress was not due to changes in the level of LexA-Sin $4 p$ or LexASrb11p (Fig. 5E). ER stress-induced transcription mediated by LexA-Sin $4 p$ or LexA-Srb11p fusion proteins in the absence of an intact classic UPR pathway was of the same magnitude as observed in $\sin 4 \Delta$ strains (Figs 3 and $4 \mathrm{~A})$. These results demonstrate that a core promoter is sufficient for induction of transcription by ER stress and that activation of a promoter in response to ER stress can be seen in a SIN4 WT background provided that transcription is artificially elevated by another means, e.g. recruitment of RNA polymerase II to a promoter. These data are also consistent with the idea that RNA polymerase II holoenzyme activity is stimulated in response to ER stress.

\section{Physiological targets for IRE1- and HAC1-independent ER stress signalling}

To analyse if IRE1- and HAC1-independent ER stress signalling targets ER chaperone genes we performed a Northern analysis. This analysis revealed that moderate activation of the ER chaperone genes KAR2, LHS1 and $P D / 1$ is retained in ire $1 \Delta$ and ire $1 \Delta \sin 4 \Delta$ strains (Fig. 6). Further, activation of the UPRE-lacZ reporter is to a large degree retained, which is consistent with our reporter assays (Fig. 3A, B), and $\mathrm{CYC1}$ shows an approximately twofold activation by ER stress in all strains. Because the UPRE-lacZ reporter is driven from the core CYC1 promoter, this finding is also consistent with our reporter assays (Fig. 3A, B). In contrast, activation of the ER chaperone genes EUG1 and SCJ1 is completely abolished in ire $1 \Delta$ strains (Fig. 6). We conclude that some ER chaperone genes are targeted by this new pathway and that a mechanism to selectively target only these promoters must exist.
CPA is a general phenomenon of stress responses

To elucidate whether ER-stress induction of CPA is a more general response to cell stress, we measured CPA induced by diverse cellular stress responses. Therefore, we assayed the expression level of the $P_{\mathrm{CrC1}(-178)}-$ lac $Z$ reporter construct before and after induction of various stresses. WT, ire $1 \Delta$, and ire $1 \Delta \sin 4 \Delta$ strains were either heat shocked, or exposed to hyper- or hypotonic conditions to induce osmotic stress. Under all conditions the ire $1 \Delta \sin 4 \Delta$ strain displayed a 1.5 - to twofold induction of $\beta$-galactosidase activity (Fig. 7). We conclude that activation of the core promoter is not limited to ER stress and a phenomenon generally associated with stress responses.

\section{Discussion}

In yeast, stress signalling from the ER to the nucleus is dependent on the type I transmembrane protein kinase/ endoribonuclease Ire1p. Ire1p regulates the synthesis of the bZIP transcription factor Hac1'p through cleavage of HAC1 mRNA. However, one-third of UPRE-lacZ reporter gene induction by ER stress was independent of IRE1 (Shamu and Walter, 1996). In this study, we show that besides the IRE1-HAC1 pathway, additional ER stress response pathway(s) culminating in transcriptional activation from a core promoter exist in Saccharomyces cerevisiae, which may be responsible for the residual, IRE1- and HAC1-independent transcriptional activation (Figs 8 and 9). Our data are consistent with ER stress stimulating RNA polymerase II holoenzyme activity in an IRE1- and HAC1-independent manner. We used random mutagenesis of an ire $1 \Delta$ strain to uncover these new pathways. Several mutations were isolated that activated a lac $Z$ reporter in response to ER stress in an IRE1-independent manner. All mutations were recessive and most comprised one complementation group. Characterization of the recessive allele of the major complementation group demonstrated that loss-of-function mutations in SIN4 allow for transcriptional activation of the lacZ reporter by ER stress independent of the classic UPR. In addition to these findings, the identical response of $\sin 4 \Delta$ and ire $1 \Delta$ $\sin 4 \Delta$ strains to ER stress (Fig. 3) suggests that $H A C 1$, IRE1 and SIN4 act in the same genetic pathway that is responsible for transcriptional activation by the classic UPR. This also explains the otherwise surprising specificity of our genetic screen for loss-of-function mutations in SIN4.

In addition to revealing transcriptional activation upon induction of ER stress, sin4 mutations elevated basal transcription of the lac $Z$ reporter construct, a phenomenon well established in previous studies (Mizuno and Harashima, 2000). Two models can explain how sin4 mutations 

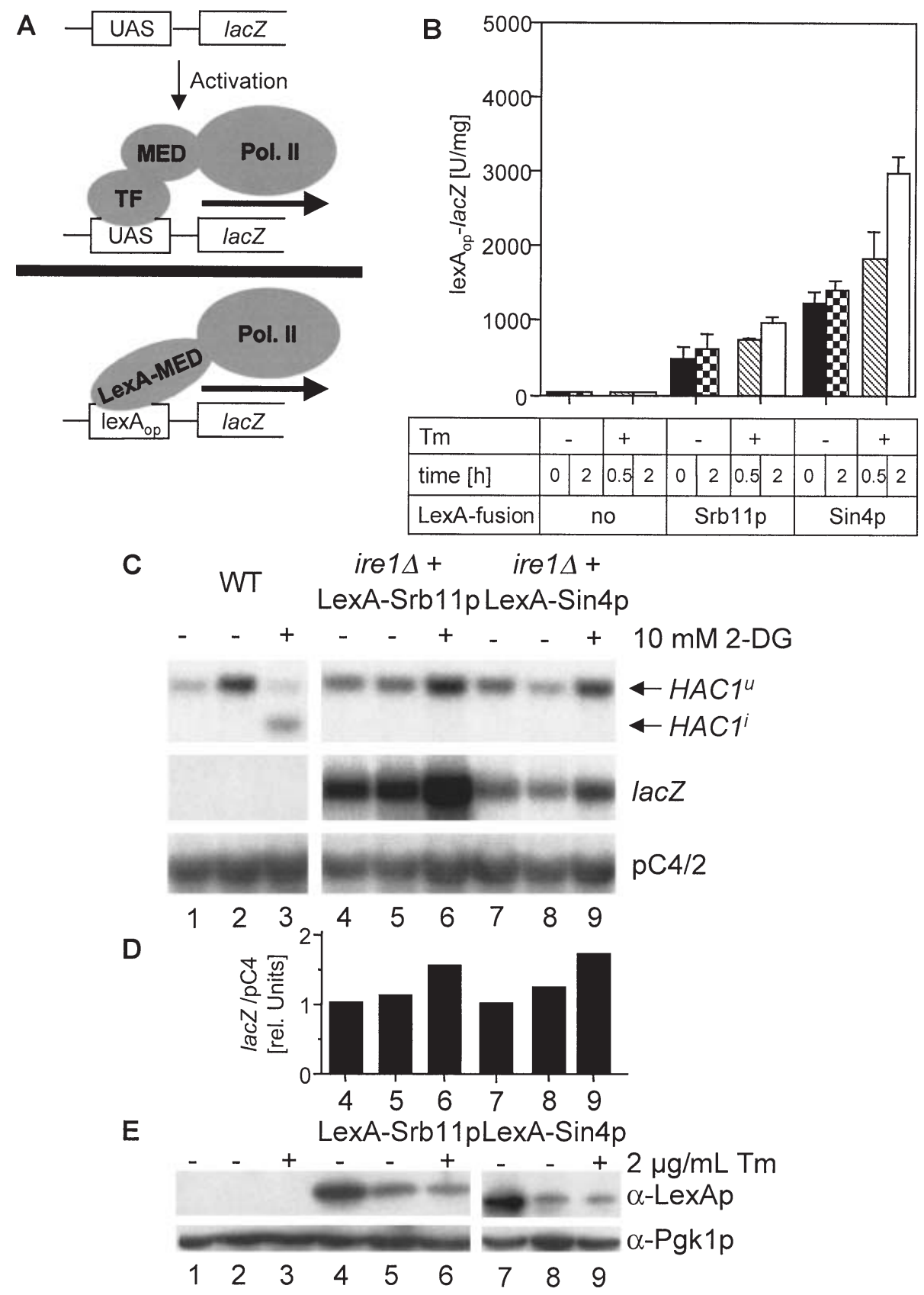

Fig. 5. ER stress increases transcription from a core promoter to which the RNA polymerase II holoenzyme is constitutively tethered in ire1 $\Delta$ cells. A. Recruitment of the RNA polymerase II holoenzyme to the promoter of a lexA $\mathrm{A}_{\mathrm{op}}$-lacZ reporter by LexAp-mediator component fusion proteins obviates the need for a transcription factor (TF). Top part: Upon an environmental stimulus a transcription factor binds to an upstream activating sequence (UAS) and recruits the RNA polymerase II holoenzyme (Pol. II) to the promoter by interaction with mediator components (MED), resulting in activation of transcription. Bottom part: The LexAp-fusions constitutively recruit the RNA polymerase II holoenzyme to the promoter, resulting in 'constitutive' activated transcription.

B. Induction of ER stress with tunicamycin $\left(0.4 \mu \mathrm{g} \mathrm{ml}^{-1}\right)$ stimulates transcription of a lexA $\mathrm{op}_{\mathrm{p}}$-lacZ reporter in an ire14 strain (MSY24-3). Similar results were obtained with three independent clones for each LexA fusion protein.

C. Northern blot and (D) quantification by Phosphorlmaging demonstrate an increase in lacZ mRNA relative to the loading control pC4/2 (Schröder et al., 2000) in an ire14 strain (MSY24-3).

E. Western blot for LexA-Sin4p and LexA-Srb11p. Mid-log phase cells were treated for $2 \mathrm{~h}$ with $10 \mathrm{mM}$ 2-deoxy-D-glucose in (C) and $2 \mu \mathrm{g} \mathrm{ml}{ }^{-1}$ tunicamycin in $(E)$ to induce $E R$ stress. 


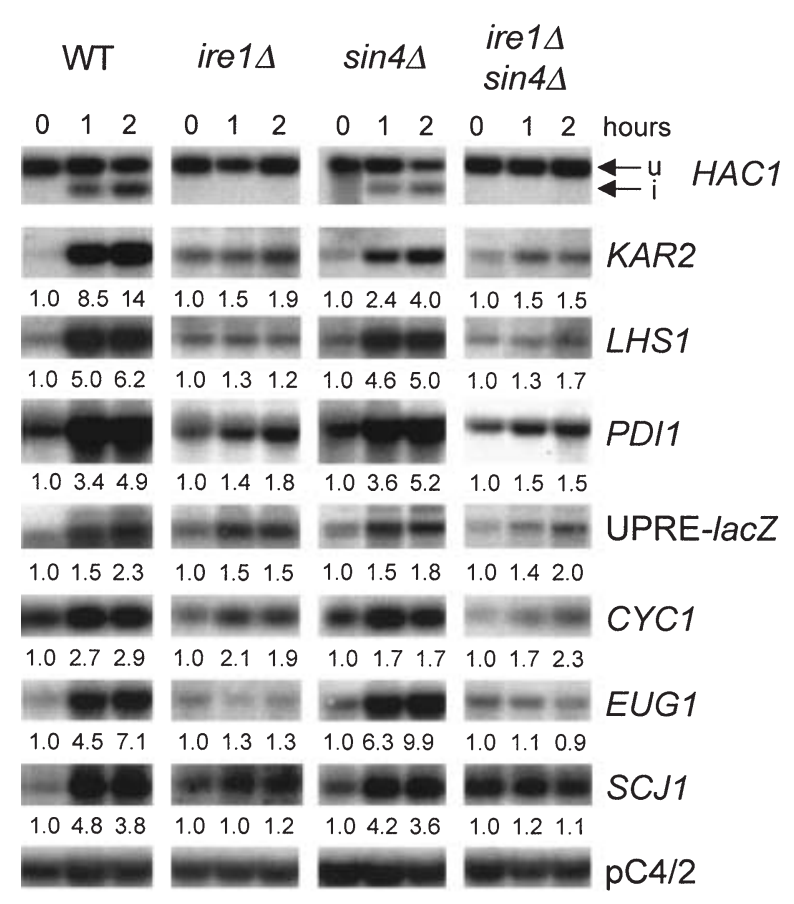

Fig. 6. Northern analysis of ER chaperone induction after treatment of WT (AWY14), ire1 1 (AWY19), sin4 (RCY7) and ire1 $\Delta \sin 4 \Delta$ (RCY8) strains with $0.2 \mu \mathrm{g} \mathrm{ml}^{-1}$ tunicamycin for 1 or $2 \mathrm{~h}$. Fold inductions are shown below each blot and were calculated as the ratio of the relative mRNA level at 1 or $2 \mathrm{~h}$ to the relative mRNA at $0 \mathrm{~h}$.

affect basal transcription (Fig. 8). In the first model (Fig. 8A), mutations in SIN4 result in less dense packing of nucleosomes on DNA (Jiang and Stillman, 1992), a chromatin structure correlating in many cases with increased transcriptional activity (Han and Grunstein, 1988; Han et al., 1988). Because sin4 mutations increase basal transcription of only a subset of genes, additional specificity factors must exist (Mizuno and Harashima, 2000). In the second model (Fig. 8B), abrogation of an interaction of $\operatorname{Sin} 4 p$ with a transcriptional repressor is responsible for increased basal transcription in $\sin 4$ mutants. $\operatorname{Sin} 4 p$ is part of a subcomplex that is dissociable from the mediator, indicating that $\operatorname{Sin} 4 p$ is distally localized in the mediator. In addition to propagating the stimulatory effect of transcriptional activators, mediator also propagates the repressing effect of Sfl1p and Tup $1 p$ to the RNA polymerase II holoenzyme (Song and Carlson, 1998; Zaman et al., 2001). Consistent with this idea are the observations that sin 4 mutations relieve repression by Rme1p (Covitz et al., 1994; Shimizu et al., 1997), by $\alpha 2-$ Mcm1p (Chen et al., 1993; Wahi and Johnson, 1995) and partially by Mig1p (Kuchin and Carlson, 1998). In addition, mutations in SRB10, encoding another component of the mediator complex, relieve repression by Tup1p (Zaman et al., 2001). The repressor can restrain the RNA polymerase II holoenzyme on the promoter through preventing access to the TATA element or by preventing release of the holoenzyme once initiation is completed.

However, both models (Fig. 8A, B) can only explain elevated basal transcription in the sin 4 strains and not stimulation of transcription in response to ER stress independent of IRE1 and HAC1 function. In the first model (Fig. 8A), activated transcription in response to ER stress requires loss of $\operatorname{Sin} 4 p$ or at least inactivation of $\operatorname{Sin} 4 p$, prior to induction and a subsequent opening of the chromatin. lacZ reporters without UPRE [Fig. 4A, see also Kohno et al. (1993) and Mori et al. (1992)] showed only a
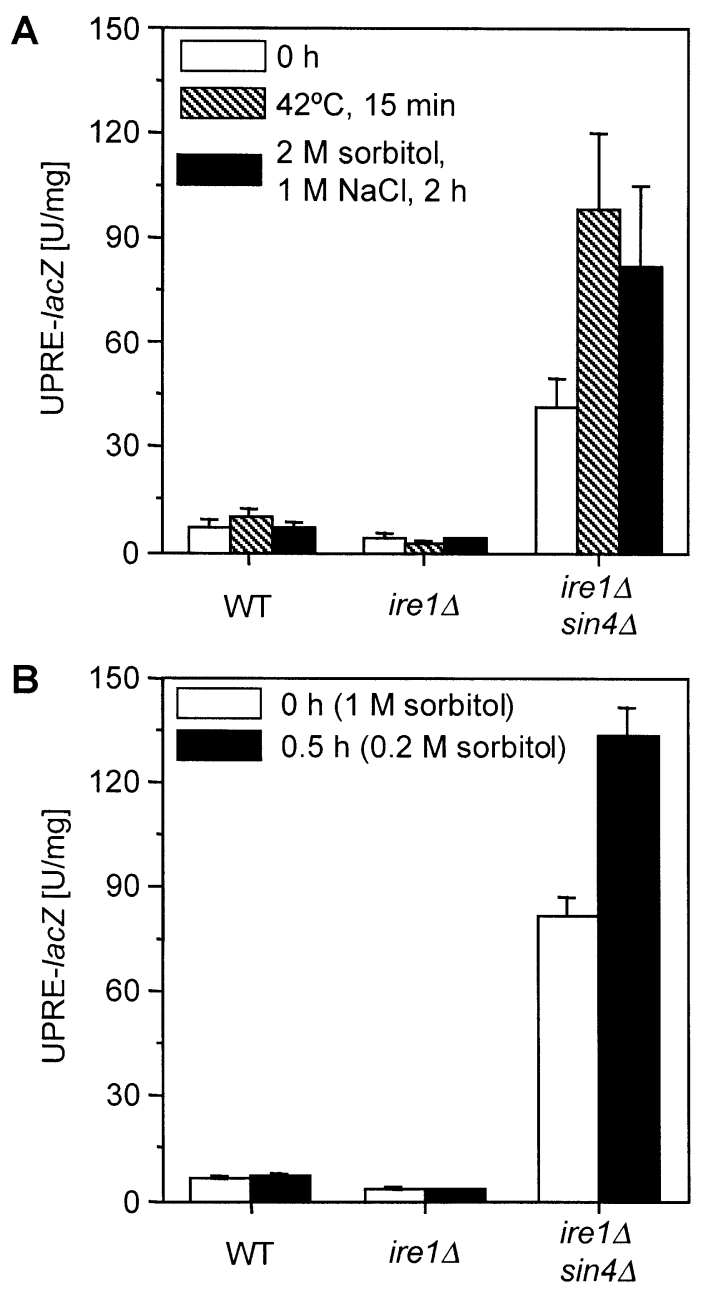

Fig. 7. Core promoter activation is a general phenomenon of stress responses.

A. Induction of a lacZ reporter containing only a core promoter by heat shock and hypertonic stress. A WT (AWY14), ire14 (AWY19) and ire $1 \Delta \sin 4 \Delta(\mathrm{RCY} 8)$ were shifted from $30^{\circ} \mathrm{C}$ to $42^{\circ} \mathrm{C}$ for $15 \mathrm{~min}$ (crossed bars), or to YPD containing $2 \mathrm{M}$ sorbitol and $1 \mathrm{M} \mathrm{NaCl}$ to induce hypertonic stress (black bars).

B. Induction of a lacZ reporter containing only a core promoter by hypotonic stress. The same strains as in (A) were shifted from YPD + $1 \mathrm{M}$ sorbitol to YPD + $0.2 \mathrm{M}$ sorbitol for $2 \mathrm{~h}$ (black bars). Open bars in $(A)$ and $(B)$ represent the expression level of the lacZ reporter before induction of stress. The average and standard error from two independent protein and $\beta$-galactosidase determinations are shown. 
A More open chromatin structure in $\sin 4 \Delta$

WT:

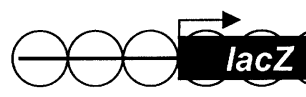

$\sin 4 \Delta:$
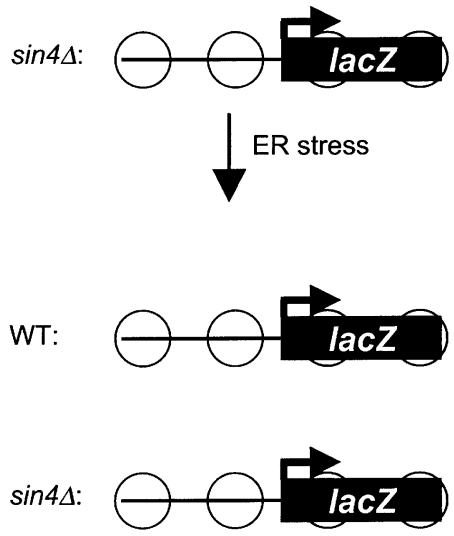

WT:
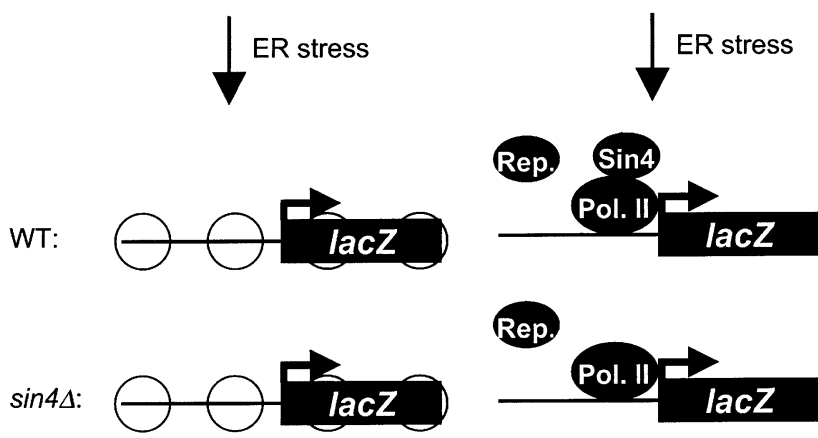

$\sin 4 \Delta:$

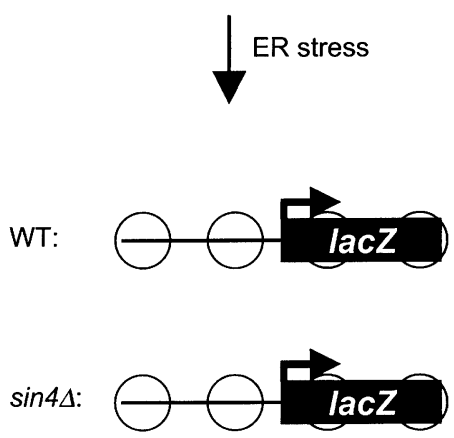

B Interaction of repressor with Pol. II abolished by $\sin 4 \Delta$
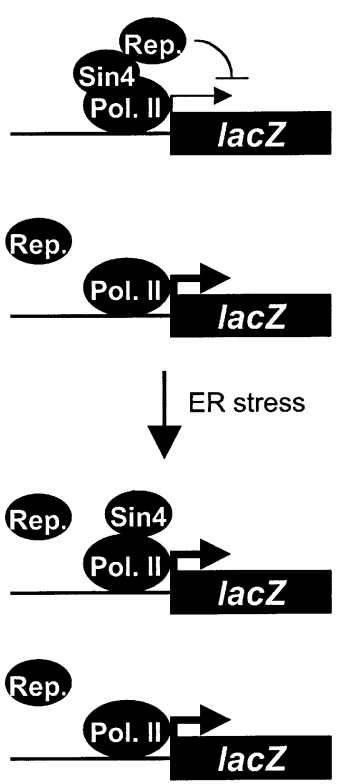

C $\sin 4 \Delta$ renders Pol. II
responsive to ER stress

D Core promoter activation (CPA)
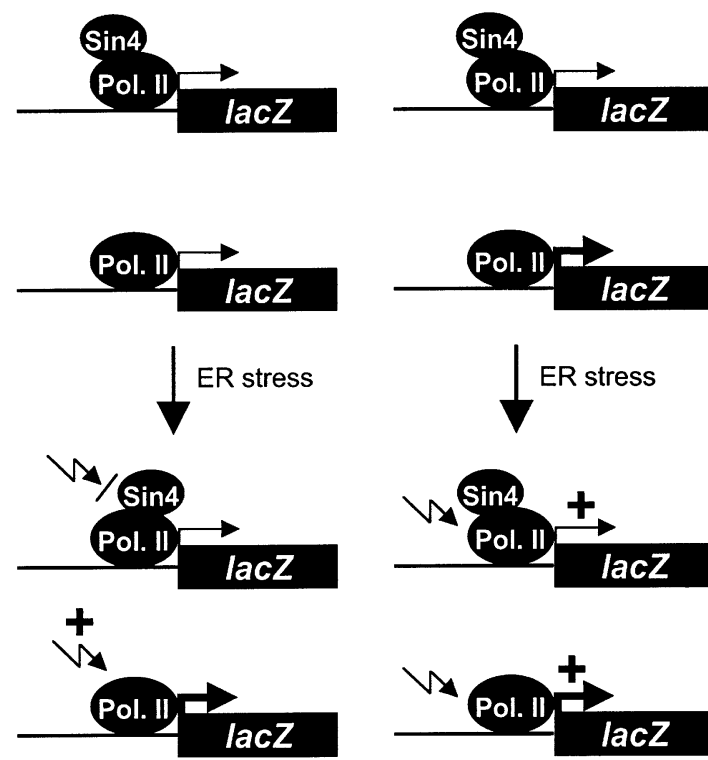

Fig. 8. Summary of models discussed in the text. Please refer to the text for details. Open circles represent nucleosomes. Pol. II: RNA polymerase II transcriptional machinery; Rep: repressor.

small, but detectable, response to ER stress in WT strains. Because $\beta$-galactosidase levels in ire $1 \Delta$ strains were significantly lower, even after induction of ER stress, than in $\sin 4 \Delta$ strains, we believe that $\operatorname{Sin} 4 p$ is intact and functional during periods of ER stress. Further, Western blot analysis demonstrated that the level of a LexA-Sin $4 p$ fusion protein was unaffected by ER stress (Fig. 5E). Thus, loss of $\operatorname{Sin} 4 p$ function as a mechanism for activated transcription upon ER stress can be ruled out. In the second model (Fig. 8B), ER stress interferes with the interaction between the repressor and $\operatorname{Sin} 4 p$. This interaction is already abolished in a $\sin 4 \Delta$ strain. We cannot rule out that the repressor contacts other components of mediator in addition to Sin4p, but at least deletion of SIN4 and GAL11 yielded opposite results (Fig. 3), indicating that the phenotype is specifically related to SIN4 and not GAL11. It is also possible that sin4 mutations render some parts of the transcriptional machinery responsive to ER stress (Fig. 8C). However, this third model is not consistent with the observation of stimulation of transcription by ER stress when the RNA polymerase II holoenzyme was tethered to a promoter in a SIN4 WT background (Fig. 5B, D). Taken together, these findings support that SIN4 does not have a direct role in the IRE1- and HAC1-independent tran-

\section{A. Classical pathway}

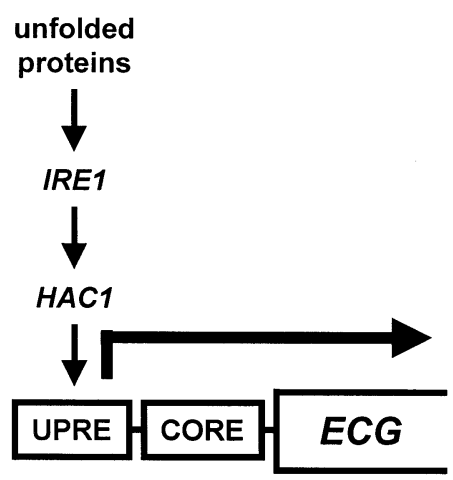

\section{B. IRE1 and HAC1 inde- pendent pathway}

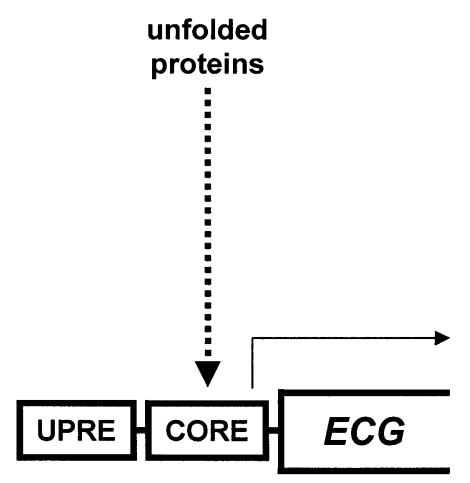

Fig. 9. Summary of unfolded protein response signalling pathways in yeast.

A. The classic pathway activates transcription of ER chaperone genes (ECG) through IRE1, $H A C 1$ and the UPRE.

B. IRE1- and HAC1-independent pathways activate transcription of some ECGs through the core promoter. A dashed line is used to indicate that the IRE1- and HAC1-independent signal transduction mechanism(s) are unknown. 
scriptional activation after induction of ER stress. We conclude that stimulation of transcription in $\sin 4 \Delta$ strains (Figs 3 and 4) or in the recruitment experiment (Fig. 5) is revealed due to the high level of basal expression prior to induction of ER stress in these systems and therefore present, but hard to detect, in WT cells.

To explain stimulation of transcription in response to ER stress in ire $1 \Delta \sin 4 \Delta$ strains (Figs 3 and 4 ) or the recruitment experiment (Fig. 5) a new signal transduction pathway from the ER to the nucleus needs to be invoked. Because this response to ER stress is fast, that is, is detectable as early as $30 \mathrm{~min}$ after induction of ER stress (Figs 1A, 3A and 4A), we think that this pathway responds to unfolded proteins in the ER lumen, and not to secondary perturbations of cellular metabolism. Two models how transcription can be stimulated in the ire $1 \Delta \sin 4 \Delta$ strains are at hand: (i) an increase in the accessibility of the promoter for the RNA polymerase II holoenzyme (Fig. 8A), or (ii) an increase in the specific activity of the holoenzyme (Fig. 8D). Examples for the first model (Fig. 8A) are changes in chromatin structure, such as less dense packaging of nucleosomes or increased histone acetylation, or binding of another, not yet identified transcriptional activator, to the promoter and subsequent recruitment of the holoenzyme to the promoter. Examples for the second model (Fig. 8D) include an intrinsic structural change in the holoenzyme, such as a post-translational modification, e.g. phosphorylation, or the addition or elimination of regulatory factors resulting in increased specific activity of the holoenzyme. This idea is not unprecedented. Direct stimulation of the holoenzyme by glucose starvation through the Snf1p kinase was recently reported (Kuchin et al., 2000). Further, genetic interactions of the hyperactive $R_{A S 2}{ }^{\text {Val19 }}$ allele with $\sin 4$, srb8, srb9, and srb11 mutations, as well as truncations of the C-terminal domain of RBP1, the largest subunit of RNA polymerase II, also suggest a direct modification of the holoenzyme, which is important for entry into stationary phase (Howard et al. 2001; Howard et al., 2002). Alternatively, these changes can affect the activity of repressors, which could, for example, result in a more rapid release of the holoenzyme once initiation is completed. To discriminate between these two possibilities, we recruited the holoenzyme to a lex $A_{o p}$-lac $Z$ reporter with LexA-holoenzyme component fusions, which should completely saturate the promoter with holoenzyme. Expression of LexA-Sin4p or LexA-Srb11p fusion proteins resulted in very strong elevation of basal transcription (Fig. 5B). Further, Western blot analysis demonstrated that the levels of both LexA-fusion proteins dropped after another $2 \mathrm{~h}$ of growth (Fig.5E), without affecting expression of the reporter significantly (Fig. 5B). These observations are consistent with saturation of the promoter with holoenzyme. We also saw stimulation of transcription after induction of ER stress in this system (Figs $5 B, C$ ). These findings are consistent with the idea that RNA polymerase II holoenzyme activity is stimulated by ER stress, and that accessibility of the promoter for the holoenzyme is not affected. However, our data cannot rule out that ER stress leads to a more elongation proficient state of the chromatin.

We term this stress-induced transcriptional activation of a core promoter core promoter activation or CPA. CPA was also observed during heat or osmotic shock and is therefore not limited to ER stress (Fig. 7). CPA may be physiologically important to further amplify a stress response by direct stimulation of holoenzyme activity, as suggested by Kuchin et al. (2000). For example, CPA contributes about $10 \%$ of the total activation of the PDI1 gene by ER stress (Fig. 6), and contributes to an even higher degree to the activation of the UPRE-lac Z reporter (Fig. 6). CPA may mediate the IRE1- and HAC1-independent transcriptional activation from a UPRE (Shamu and Walter, 1996). Modest activation of a subset of ER chaperone genes was observed in ire $1 \Delta$ and ire $1 \Delta \sin 4 \Delta$ strains (Fig. 6). This demonstrates that CPA indeed targets some, but not all, ER chaperone genes. Alternatively, CPA can be responsible for a genome-wide modulation of transcription (Kuchin et al., 2000), or constitute a pathway separate from the classic UPR and then be responsible for induction of a separate set of genes for which a moderate induction level is sufficient to contribute to cell survival during stress conditions. These functions are supported by three observations: First, survival of ER stress by ire $1 \Delta \sin 4 \Delta$ strains is improved compared with ire $1 \Delta$ strains (Figs 2B and 4B). Second, CYC1 is about twofold induced upon ER stress in an IRE1-independent manner (Fig. 6). Third, most of the 87 genes that were identified as ER stress responsive in an IRE1- and HAC1-independent manner encode functions that could protect from ER stress (Table 1; Travers et al., 2000). In this case, CPA may play a role in activation of many genes in response to stress conditions. Last, direct stimulation of holoenzyme activity may be the most archaic stress response that evolved long before nature invented more specialized transcriptional regulators. In this case we expect this mechanism to be also present in higher eukaryotes.

In conclusion, the data provided in this study demonstrate that moderate transcriptional activation of a core promoter occurs after induction of ER stress, and that the classic UPR, that is, IRE1, HAC1 and an UPRE, are dispensable for this response (Fig. 9). These findings provide a plausible explanation for the residual activation of transcription in an IRE1- and HAC1-independent fashion reported earlier (Shamu and Walter, 1996). Further, our data indicate that increased transcription after induction of ER stress in ire1 $1 \Delta$ cells is not due to changes in promoter accessibility, but rather an intrinsic structural change that increases RNA polymerase II holoenzyme activity. Future work will address the question how the 
Table 1. Open reading frames (ORF) induced in an IRE1- and HAC1-independent manner by ER stress with a likely function in alleviating ER stress.

\begin{tabular}{|c|c|c|c|c|c|c|c|c|}
\hline \multirow[b]{2}{*}{ Gene } & \multicolumn{2}{|c|}{ WT } & \multicolumn{2}{|c|}{ ire14 } & \multicolumn{2}{|c|}{ hac1s } & \multirow[b]{2}{*}{ Function/description } & \multirow{2}{*}{$\begin{array}{l}\text { Relation to } \\
\text { ER stress }\end{array}$} \\
\hline & DTT & $\mathrm{Tm}$ & DTT & $\mathrm{Tm}$ & DTT & $\mathrm{Tm}$ & & \\
\hline SSA4 & 3.5 & 5.8 & 22.5 & 11.6 & 11.4 & 8.6 & Heat shock protein & Y \\
\hline UBC5 & 1.7 & 1.7 & 2.3 & 7.5 & 4.4 & 4.6 & Ubiquitin conjugating enzyme & $\mathrm{Y}$ \\
\hline HSP26 & 2.6 & 1.9 & 6.3 & 5.7 & 6.0 & 5.5 & Heat shock protein & $\mathrm{Y}$ \\
\hline KTR2 & 5.7 & 4.5 & 8.4 & 4.8 & 2.9 & 2.9 & Mannosyltransferase & $\mathrm{Y}$ \\
\hline GFA1 & 5.3 & 4.3 & 7.1 & 4.6 & 1.3 & 1.3 & $\begin{array}{l}\text { Glucosamine-fructose-6-phosphate } \\
\text { aminotransferase (isomerizing) }\end{array}$ & $\mathrm{Y}$ \\
\hline$N D / 1$ & 2.3 & 2.9 & 2.0 & 4.5 & 1.3 & 1.9 & NADH dehydrogenase (ubiquinone) & $\mathrm{Y}$ \\
\hline HVG1 & 6.9 & 5.2 & 9.1 & 4.2 & 3.6 & 3.2 & Nucleotide sugar transporter & $\mathrm{Y}$ \\
\hline PKH2 & 2.6 & 2.5 & 3.9 & 4.1 & 3.8 & 3.0 & Pkb-activating kinase homologue & ? \\
\hline GSC2 & 9.6 & 4.8 & 4.8 & 3.5 & 4.9 & 2.0 & 1,3- $\beta$-glucan synthase & $\mathrm{Y}$ \\
\hline SLT2 & 3.1 & 3.6 & 4.5 & 3.5 & 2.5 & 2.4 & MAP kinase, cell wall defects & ? \\
\hline HSP42 & 2.3 & 2.4 & 4.6 & 3.4 & 8.2 & 7.0 & Heat shock protein & $\mathrm{Y}$ \\
\hline SUR1 & 1.2 & 1.9 & 2.8 & 3.4 & 2.6 & 2.6 & Involved in maintenance of phospholipid levels & $\mathrm{Y}$ \\
\hline SSE2 & 3.3 & 2.9 & 3.5 & 3.1 & 3.6 & 4.3 & Heat shock protein & Y \\
\hline BAG7 & 2.3 & 1.4 & 2.8 & 3.1 & 1.6 & 2.5 & Rho GTPase activator & ? \\
\hline CSI2 & 3.9 & 5.2 & 4.8 & 3.1 & 2.7 & 1.9 & Structural component of chitin synthase 3 complex & $\mathrm{Y}$ \\
\hline$A L D 3$ & 2.6 & 1.6 & 3.0 & 3.1 & 2.0 & 1.3 & $\begin{array}{l}\text { Aldehyde dehydrogenase, induced in response to } \\
\text { heat shock }\end{array}$ & Y \\
\hline$D D R 48$ & 7.1 & 3.7 & 5.4 & 3.0 & 5.5 & 2.2 & DNA repair & $\mathrm{N}$ \\
\hline UBI4 & 2.4 & 1.8 & 4.2 & 2.9 & 3.0 & 2.4 & Protein degradation tagging & $\mathrm{Y}$ \\
\hline YPS3 & 3.4 & 2.3 & 3.1 & 2.9 & 3.4 & 6.6 & GPI-anchored aspartic-type endopeptidase & Y \\
\hline AUT7 & 1.8 & 1.9 & 3.5 & 2.9 & 3.2 & 4.5 & Autophagy & $\mathrm{Y}$ \\
\hline PCL1 & 5.1 & 5.3 & 3.9 & 2.9 & 4.3 & 3.0 & $\mathrm{G}_{1}$-cyclin that associates with $\mathrm{PHO} 85$ & $\mathrm{~N}$ \\
\hline SKM1 & 1.8 & 1.9 & 3.1 & 2.9 & 3.1 & 2.6 & Protein kinase, cell cycle control & $\mathrm{N}$ \\
\hline MAG1 & 1.6 & 1.8 & 4.1 & 2.9 & 2.6 & 2.3 & 3-methyladenine DNA glycosylase & $\mathrm{N}$ \\
\hline $\mathrm{OCH} 1$ & 3.0 & 2.3 & 3.8 & 2.7 & 5.1 & 2.7 & $\alpha-1,6$-mannosyltransferase & $\mathrm{Y}$ \\
\hline AFR1 & 2.1 & 2.8 & 2.9 & 2.3 & 2.2 & 2.8 & Mating response & ? \\
\hline TPS2 & 2.1 & 1.7 & 2.3 & 2.3 & 4.6 & 2.7 & Trehalose phosphatase, stress response & $\mathrm{Y}$ \\
\hline HSP82 & 1.1 & 2.1 & 2.9 & 2.2 & 7.7 & 9.0 & Heat shock protein & $\mathrm{Y}$ \\
\hline HSP104 & 1.3 & 1.5 & 3.0 & 2.2 & 5.5 & 5.3 & Heat shock protein & Y \\
\hline YPS1 & 8.0 & 4.3 & 2.7 & 2.1 & 5.9 & 4.4 & GPI-anchored aspartic protease & Y \\
\hline APG7 & 2.0 & 1.8 & 3.2 & 2.1 & 2.3 & 2.8 & Ubiquitin-like conjugating enzyme, autophagy & $\mathrm{Y}$ \\
\hline SDS22 & 2.1 & 1.8 & 2.8 & 2.1 & 2.5 & 2.1 & Glc7p regulatory subunit & Y \\
\hline
\end{tabular}

The fold inductions after treatment with $2 \mathrm{mM}$ DTT or $1 \mu \mathrm{g} \mathrm{ml}^{-1}$ tunicamycin (Tm) for $1 \mathrm{~h}$ are reproduced from Travers et al. (2000). The genes were sorted on the basis of their extent of induction with tunicamycin in the ire1 $1 \Delta$, and then hac1 $1 \Delta$ strain. Only genes with a well-characterized

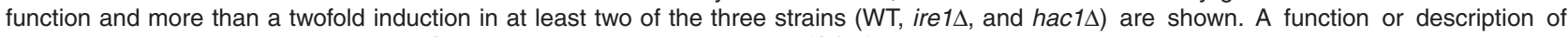
each gene is given, as provided by the Saccharomyces genome database (SGD). A putative relation to perturbation of secretory pathway function is denoted by a ' $Y$ ' for yes and ' $N$ ' for no. A question mark (?) is used in cases where, due to limited information, no decision could be made.

activity of the holoenzyme is regulated, and what signalling pathways are involved.

\section{Experimental procedures}

\section{Strains and plasmids}

Escherichia coli $\mathrm{DH} 10 \mathrm{~B}$ (Invitrogen) was used for all cloning

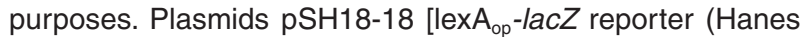
and Brent, 1989)], pSK34 [LexA-Srb11p (Kuchin et al., 2000)] and pSK151 [LexA-Sin4p (Kuchin et al., 2000)] were a gift of M. Carlson (Columbia University, New York, NY). Saccharomyces cerevisiae strains are summarized in Table 2.

\section{Genomic manipulations}

IRE1 was deleted as described before (Schröder et al., 2000). ura3-1 strains were transformed to uracil prototrophy using Ncol-linearized pRS306 (Sikorski and Hieter, 1989). To delete HAC1, the $1.2 \mathrm{~kb} K$ pnl-Xbal piece of pHAKO1 (Cox and Walter, 1996) was cloned into the Kpnl-Xbal sites of Ylplac204 (Gietz and Sugino, 1988) to yield p $\Delta$ hac1::TRP1. Correct integration of $B a m H l$-linearized $p \Delta$ hac1::TRP1 into the HAC1 locus was verified by PCR with primers $5413 \mathrm{G}$ (Table 3 ) and $4149 \mathrm{~K}$, and by Southern analysis. SIN4 and YTP1 were deleted either by PCR-mediated gene disruption using the kanMX2-cassette of pFA6a (Wach et al., 1994) and oligonucleotide pairs $8701 \mathrm{G}, 8702 \mathrm{G}$ and $8699 \mathrm{G}, 8700 \mathrm{G}$ or with $B a m H I$-linearized plasmid $\mathrm{p} \Delta \sin 4:: U R A 3$ in the case of SIN4. To construct p $\Delta \sin 4:: U R A 3$, the $5^{\prime}$ - and $3^{\prime}$-piece of the SIN4 locus were amplified from genomic DNA with oligonucleotides $1684 \mathrm{~K}, 1685 \mathrm{~K}, 1686 \mathrm{~K}$ and $1687 \mathrm{~K}$ respectively. The PCR products were fused by overlapping PCR and cloned into the Spel-Xhol sites of pRS306. Integration of the PCR generated deletion constructs into the SIN4 and YTP1 loci was verified with primers $7256 \mathrm{G}, 9059 \mathrm{~J}$, and 9060J. Correct integration of BamHI-linearized $\mathrm{p} \Delta \sin 4:$ URA3 into the SIN4 locus was verified with primers $2742 \mathrm{~K}$ and $2743 \mathrm{~K}$. GAL11 was deleted by PCR-mediated gene disruption using the nourseothricin resistance gene in pAG25 (Goldstein and 
Table 2. Yeast strains.

\begin{tabular}{|c|c|c|}
\hline Strain & Genotype & Source \\
\hline W303 1A & MATa & A. Welihinda \\
\hline W303 1B & MAT $\alpha$ & A. Welihinda \\
\hline AWY 14 & MATa UPRE-P ${ }_{\mathrm{CYC1(-178)}}-$ LEU2::HIS3 UPRE-P ${ }_{\mathrm{CYC1(-178)}}-$ lacZ::TRP1 & Liu et al. (2000) \\
\hline AWY 19 & MATa UPRE-P ${ }_{\mathrm{CYC} 1(-178)}$-LEU2::HIS3 UPRE-P ${ }_{\mathrm{CYC1(-178)}}$-lacZ::TRP1 ire1A & Liu et al. (2000) \\
\hline RCY 7 & MATa UPRE-P ${ }_{\mathrm{CYC1(-178)}}$-LEU2::HIS3 UPRE-P ${ }_{\mathrm{CYC1(-178)}}$-lacZ::TRP1 $\sin 4 \Delta:: k a n M X 2$ & This study \\
\hline RCY 8 & 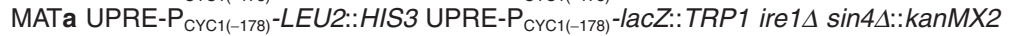 & This study \\
\hline RCY 9 & MATa UPRE-P ${ }_{\mathrm{CYC1(-178)}}-$ LEU2::HIS3 UPRE-P $\mathrm{CYC1(-178)}^{-l a c Z:: T R P 1 ~ i r e 1 \Delta ~ y t p 1 \Delta:: k a n M X 2 ~}$ & This study \\
\hline MSY 293-01 & 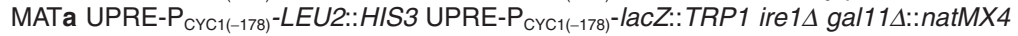 & This study \\
\hline AWY 500 & MAT $\alpha$ UPRE-P ${ }_{\text {CYC1(-178) }}$-lacZ::LEU2 & Welihinda et al. (1998) \\
\hline AWY 503 & MAT $\alpha$ UPRE-P ${ }_{\text {CYC1(-178)-lacZ::HIS3 }}$ & A. Welihinda \\
\hline MSY 6 & MAT $\alpha$ UPRE-P ${ }_{\text {CYC1(-178)-lacZ::LEU2 ire1 } 1 \Delta:: k a n M X 2}$ & this study \\
\hline MSY 7 & MAT $\alpha$ UPRE-P ${ }_{\text {CYC1(-178) }}$-lacZ::HIS3 ire14::kanMX2 & this study \\
\hline MSY 8 & MAT $\alpha$ UPRE-P ${ }_{\text {CYC1(-178) }}$-lacZ::LEU2 ire14::kanMX2 ura3-1::URA3 & this study \\
\hline MSY 9-1 & MAT $\alpha$ UPRE-P ${ }_{\text {CYc1(-178) }}$-lacZ::HIS3 ire14::kanMX2 ura3-1::URA3 & This study \\
\hline MSY 24-3 & MATa ire1 $1:: k a n M X 2$ & This study \\
\hline RCY 1 & MATa UPRE-P ${ }_{\mathrm{CYC1(-178)}}-\mathrm{lacZ::HIS3} \mathrm{ire1 \Delta ::kanMX2}$ & This study \\
\hline RCY 2 & MATa $P_{\text {CYC1(-178)-lacZ::HIS3 ire14::kanMX2 }}$ & This study \\
\hline RCY 3 & 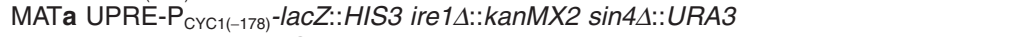 & This study \\
\hline RCY 4 & 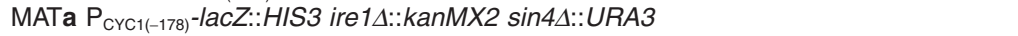 & This study \\
\hline RCY 5 & MATa UPRE-P ${ }_{\mathrm{CYC1}(-178)}-l a c Z:: H I S 3$ ire $1 \Delta:: k a n M X 2$ hac1 $::$ TRP1 $\sin 4 \Delta:: U R A 3$ & This study \\
\hline RCY 6 & 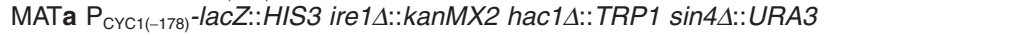 & This study \\
\hline
\end{tabular}

All strains are in the W303-1 genetic background and carry the mutations ade2-1, can1-100, his3-11,-15, leu2-3,-112, trp1-1, ura3-1.

McCusker, 1999) and oligonucleotides 5578K and 5579K. Correct integration of the deletion construct into the GAL11 locus was verified with primers 6016K, 7305K and 3169I. Plasmid pJC002 (Cox et al., 1993) contains the lacZ gene under control of an UPRE inserted into the Bg/l-Xhol sites of the core CYC1 promoter up to basepair -178. We designate this reporter construct as UPRE-P $\mathrm{CYC1}_{\text {(-178)-lacZ. To con- }}$ struct a reporter plasmid lacking the UPRE, pJC002 was digested with $X$ hol and religated to remove the UPRE sequence to yield pJC002-UPRE ( $P_{\mathrm{CYC1} 1(-178)}$-lacZ). Both, pJC002 and pJC002-UPRE were linearized with Nhel and integrated into the HIS3 locus. Integration into the HIS3 locus was verified by PCR on the $5^{\prime}$ end of the recombined locus with primers $798 \mathrm{~K}$ and $799 \mathrm{~K}$. All transformations were done using the LiOAc-method (Chen et al., 1992).

\section{Media, growth conditions and stress induction}

Yeast extract-peptone-dextrose (YPD) and synthetic dextrose (SD) media were described previously (Sherman, 1991). For plates, 2\% (w/v) bacto-agar (Difco) was added. G418 (Invitrogen) and nourseothricin (Werner Bioagents) were used at $400 \mathrm{mg} \mathrm{l}^{-1}$ and $25 \mathrm{mg} \mathrm{l}^{-1}$ respectively. To monitor induction of lac $Z$ reporters on plates, $0.1 \mathrm{M}$ sodium phosphate $(\mathrm{pH} 7.0)$, $50 \mathrm{mg} \mathrm{ml}^{-1} \quad$ 5-bromo-4-chloro-3-indolyl- $\beta$-D-galactopyranoside (Xgal; Diagnostic Chemicals) and $2 \mathrm{mg} \mathrm{ml}^{-1}$ tunicamycin (Calbiochem) were added. To induce unfolded proteins in the ER lumen in liquid culture, 0.4 or $2 \mathrm{mg} \mathrm{ml}^{-1}$ tunicamycin were added to mid-log phase cultures. Alternatively, 2-deoxy-Dglucose or dithiothreitol (DTT) were used at 10 or $3 \mathrm{mM}$ respectively. Resistance to tunicamycin and 2-deoxy-D-glucose was assayed by spotting 10-fold serial dilutions of freshly grown overnight cultures onto YPD or SD plates containing increasing concentrations of the drugs. The plates were then incubated at $30^{\circ} \mathrm{C}$ for $2-3$ days. Heat shock was induced by shifting cells from $30^{\circ} \mathrm{C}$ to $42^{\circ} \mathrm{C}$ for $15 \mathrm{~min}$. Hypertonic stress was induced by shifting cells from YPD to YPD $+2 \mathrm{M}$ sorbitol $+1 \mathrm{M} \mathrm{NaCl}$ for $2 \mathrm{~h}$, and hypotonic stress by shifting cells grown in YPD + $1 \mathrm{M}$ sorbitol to YPD + $0.2 \mathrm{M}$ sorbitol for $2 \mathrm{~h}$.

\section{Isolation of eis (ERN1-independent signalling) mutations}

ire1 $\Delta$ strains (AWY19 and MSY9-1) were mutagenized with $3 \%(\mathrm{v} / \mathrm{v})$ ethyl methanesulfonate (Sigma) as described by Lawrence (1991). Cells were first selected for resistance to tunicamycin (0.1-0.25 $\mu \mathrm{g} \mathrm{ml}^{-1}$ tunicamycin) and resistant colonies then screened for induction of the UPRE- $P_{\mathrm{CYC1}(-178)}-\mathrm{lac} Z$ reporter by replica plating to YPD-X-Gal and YPD-X-Galtunicamycin plates. Colonies that developed a blue colour in the presence of tunicamycin were isolated. Dominance, recessiveness and complementation groups were established using classic yeast genetic methods.

\section{Cloning of EIS1}

Recessive mutations were cloned by complementation (Rose and Broach, 1991) using a yeast genomic DNA library in YCp50 [ATCC 37415 (Rose et al., 1987)]. Approximately 31000 transformants were analysed for induction of the lacZ reporter in response to ER stress. Colonies showing complementation by the plasmid were further tested for sensitivity to $0.2 \mu \mathrm{g} \mathrm{m}^{-1}$ tunicamycin. A total of 28 complementing clones were obtained. Plasmid DNA was isolated from these clones (Strathern and Higgins, 1991) and electroporated (Seidman et al., 2000) into E. coli DH10B. Sequencing of the $5^{\prime}$ and $3^{\prime}$ ends identified the inserts in YCp50. All plasmids were reintroduced into yeast to verify their ability to complement the recessive mutation. 
Table 3. Oligonucleotides.

\begin{tabular}{|c|c|}
\hline Name & Sequence $\left(5^{\prime}\right.$ to $\left.3^{\prime}\right)$ \\
\hline $5413 \mathrm{G}$ & CTATTGAGCTCCTGTCTTCCTCTACTGGGC \\
\hline $7256 \mathrm{G}$ & CGCGGCCTCGAAACGTGA \\
\hline $8699 G$ & $\begin{array}{l}\text { GGAGCAAGGTATTGGAATGAATGTATTTTTGTCC } \\
\text { AGCGTTCTTTTATCACGAGGCCACTAGTGGA } \\
\text { TCTG }\end{array}$ \\
\hline $8700 \mathrm{G}$ & $\begin{array}{l}\text { CCTTACCTGCCTAGAAGGAATGACAGCAGCTAA } \\
\text { TAAGAATATTGTCTTCGAAGCTTCGTACGCTG } \\
\text { CAG }\end{array}$ \\
\hline $8701 \mathrm{G}$ & $\begin{array}{l}\text { AATAACGTTACAGCTGCTGGACACTTCAAATCA } \\
\text { AGATTCAAGGATCTTCAAGCTTCGTACGCTG } \\
\text { CAG }\end{array}$ \\
\hline $8702 \mathrm{G}$ & $\begin{array}{l}\text { CATTTCTTCAATATTTTCTTGGCGAAAAACAACTG } \\
\text { CCAAGTTCCAGCTGCAAGGCCACTAGTGGA } \\
\text { TCTG }\end{array}$ \\
\hline $9059 \mathrm{~J}$ & GCAGCCGCATTCGCATGG \\
\hline 9060J & ATGGTCGCCTCCCAACCG \\
\hline $798 \mathrm{~K}$ & CTGCCAGGTATCGTTTGAAC \\
\hline $799 \mathrm{~K}$ & ACGCATCTGTGCGGTATTTC \\
\hline $1674 \mathrm{~K}$ & CAGGCGCATTTTTTGGTCTAC \\
\hline $1675 \mathrm{~K}$ & GAGAGAAATCGCTACCCTTG \\
\hline $1684 \mathrm{~K}$ & $\begin{array}{l}\text { GCTAGATAACATATGGATCCAAGATGTGGATGAA } \\
\text { GATACC }\end{array}$ \\
\hline $1685 \mathrm{~K}$ & CTACTTTCTCGAGATTGAACTTCGTGCAATTGC \\
\hline $1686 \mathrm{~K}$ & CTCATTCACTAGTTGATTCCTGTTGCTAAATGG \\
\hline $1687 \mathrm{~K}$ & GGATCCATATGTTATCTAGCTCCCTCTTCTAATGG \\
\hline $2742 \mathrm{~K}$ & TGTGGTCTCTACAGGATCTG \\
\hline $2743 \mathrm{~K}$ & CACAGGTTACATCGTCGTAC \\
\hline $3490 \mathrm{~K}$ & ССТACACССТСTTTGTTAGA \\
\hline $3491 \mathrm{~K}$ & AACTAGCAGACCTGACCTTC \\
\hline $3492 \mathrm{~K}$ & TGGAAGCACTCCAAACTTCG \\
\hline $3493 \mathrm{~K}$ & CTTGGAATTTCGCTGGCTCA \\
\hline $3494 \mathrm{~K}$ & CACCTATGAATGATGATCAG \\
\hline $3495 \mathrm{~K}$ & GCTCCAACACAACTTTCAGC \\
\hline $3496 \mathrm{~K}$ & TATTGCATCCCCACTAAGCG \\
\hline $3497 \mathrm{~K}$ & CATTTCTCCTGATGCGCCTA \\
\hline $3498 \mathrm{~K}$ & CACAAACAAGGAATACACAC \\
\hline $3499 \mathrm{~K}$ & GAATATGCCAAAGTGGGAGA \\
\hline $3500 \mathrm{~K}$ & TAAGAGATGCAGTAGGTGCG \\
\hline $3501 \mathrm{~K}$ & ACAAAGGAGACTAACGAAGG \\
\hline $3502 \mathrm{~K}$ & TGGCATTTGAGGACTGTGAG \\
\hline $3503 \mathrm{~K}$ & GATCAGGACGTTGTCCAGTA \\
\hline $3504 \mathrm{~K}$ & TTCCTTATTGCCAAGCACGC \\
\hline $3505 \mathrm{~K}$ & TAGACACAACATGCAGGTTC \\
\hline $3506 \mathrm{~K}$ & ACGATATCACTGTGGCGACG \\
\hline $3507 \mathrm{~K}$ & CACGTATCCAAATGCCAAAG \\
\hline $3508 \mathrm{~K}$ & CCACACCATTGAACGCAAAC \\
\hline $3509 \mathrm{~K}$ & TTCGCCACTATTTGGGTGAC \\
\hline $3510 \mathrm{~K}$ & TCAAGCCACTTGTATCTGCA \\
\hline $4149 \mathrm{~K}$ & TGTAAGCGGAGGTGTGGAG \\
\hline $3511 \mathrm{~K}$ & ACCTGAACATATGCACAGTC \\
\hline $5578 \mathrm{~K}$ & $\begin{array}{l}\text { TCATGGACATTAACACTCTGAACGGAGGGAGC } \\
\text { TCCGACACTGCTGATAAGAAGCTTCGTACGC } \\
\text { TGCAGG }\end{array}$ \\
\hline $5579 \mathrm{~K}$ & $\begin{array}{l}\text { ACCCATAGGAGACTGTACAGTCTTCATATTATTG } \\
\text { GGGTTTGGTGTGCCATAGGCCACTAGTGGAT } \\
\text { CTG }\end{array}$ \\
\hline $6016 \mathrm{~K}$ & CGTATCGTTTCGTATAGTGC \\
\hline $6932 \mathrm{~K}$ & GATGGTAGTGGTCAAATGGC \\
\hline $6933 \mathrm{~K}$ & CAACTGGTAATGGTAGCGAC \\
\hline $7305 \mathrm{~K}$ & AGGTGCCACTTTCATCTGG \\
\hline $3169 \mathrm{~L}$ & CCGTGTCGTCAAGAGTGG \\
\hline
\end{tabular}

\section{Sequencing of $\sin 4$ alleles}

The complete wild type (WT) and mutant sin4-68 ORF were amplified with Pwo DNA Polymerase (Roche Molecular Bio- chemicals) using primers $1674 \mathrm{~K}$ and $1675 \mathrm{~K}$, and cloned into the EcoRl-Xbal sites of pRS306. Both strands were sequenced with primers $3490 \mathrm{~K}$ to $3511 \mathrm{~K}$. Two independent bacterial clones were analysed to eliminate mutations introduced during PCR.

\section{$\beta$-Galactosidase assays}

To assay induction of the lacZ reporter in response to ER stress in liquid culture, cells were grown to mid-log phase, drugs added at the concentration stated in the text, and samples taken before, 30 and $120 \mathrm{~min}$ after addition of the drug. The preparation of protein extracts, the determination of protein concentrations and $\beta$-galactosidase activity were previously described (Schröder et al., 2000). $\beta$-Galactosidase was standardized in all experiments to the amount of intracellular protein.

\section{RNA preparation and analysis}

Isolation and Northern analysis of RNA, the probes for HAC1 and the loading control pC4/2 were described previously (Schröder et al., 2000). The lacZ probe was amplified by PCR with primers 6932K and 6933K from plasmid Z691 (Mori et al., 1993) as template. Probes for CYC1, EUG1, LHS1, KAR2, PDI1 and SCJ1 were amplified from genomic yeast DNA. All signals were quantified by Phosphorlmaging (Molecular Dynamics) and standardized to the loading control pC4/2.

\section{Western blots}

To determine protein concentrations, protein was extracted as previously described (Kuchin et al., 2000), diluted 1:30 into $0.1 \mathrm{M}$ 2-iodoacetamide in $0.1 \mathrm{M}$ Tris- $\mathrm{HCl}(\mathrm{pH} 8.0)$, and then incubated $15 \mathrm{~min}$ at $37^{\circ} \mathrm{C}$ to destroy $\beta$-mercaptoethanol. Protein was then determined using the Bio-Rad DC kit (BioRad). Immunoblotting with goat- $\alpha$-LexA-antibody (Invitrogen) and mouse- $\alpha$-Pgk1p-antibody (Molecular Probes) as primary antibodies and rabbit- $\alpha$-goat-IgG-horseradish peroxidase (1:5000, Invitrogen) or goat- $\alpha$-mouse-IgG-POD (1:400, Roche Molecular Biochemicals) as secondary antibodies was done according to each manufacturer's instructions. Blots were stripped for $10 \mathrm{~min}$ at room temperature with $0.1 \mathrm{M}$ glycine. $\mathrm{HCl}(\mathrm{pH} 2.5)$. Chemiluminescence detection was performed as described previously (Schröder and Friedl, 1997).

\section{Acknowledgements}

We thank Dr Ajith A. Welihinda (Galileo Laboratories, Santa Clara, CA) for strains and plasmids, Marian Carlson for kindly providing plasmids, Jason S. Chang for technical assistance, and Dennis Thiele (University of Michigan, Ann Arbor, MI) for use of the Fotodyne electronic imaging system (Fotodyne, Hartland, WI). We also thank Jan Mitchell for critically reading the manuscript.

\section{References}

Bertolotti, A., Zhang, Y., Hendershot, L.M., Harding, H.P., 
and Ron, D. (2000) Dynamic interaction of BiP and ER stress transducers in the unfolded-protein response. Nature Cell Biol 2: 326-332.

Calfon, M., Zeng, H., Urano, F., Till, J.H., Hubbard, S.R., Harding, H.P., et al. (2002) IRE1 couples endoplasmic reticulum load to secretory capacity by processing the XBP-1 mRNA. Nature 415: 92-96.

Carlson, M. (1997) Genetics of transcriptional regulation in yeast: connections to the RNA polymerase II CTD. Annu Rev Cell Dev Biol 13: 1-23.

Chapman, R.E., and Walter, P. (1997) Translational attenuation mediated by an mRNA intron. Curr Biol 7: 850-859.

Chen, D.-C., Yang, B.-C., and Kuo, T.-T. (1992) One steptransformation of yeast in stationary phase. Curr Genet 21: 83-84.

Chen, S., West, R.W., Johnson, S.L., Gans, H., Kruger, B., and Ma, J. (1993) TSF3, a global regulatory protein that silences transcription of yeast GAL genes, also mediates repression by $\alpha 2$ repressor and is identical to SIN4. Mol Cell Biol 13: 831-840.

Covitz, P.A., Song, W., and Mitchell, A.P. (1994) Requirement for RGR1 and SIN4. RME1-dependent repression in Saccharomyces cerevisiae. Genetics 138: 577-586.

Cox, J.S., and Walter, P. (1996) A novel mechanism for regulating activity of a transcription factor that controls the unfolded protein response. Cell 87: 391-404.

Cox, J.S., Shamu, C.E., and Walter, P. (1993) Transcriptional induction of genes encoding endoplasmic reticulum resident proteins requires a transmembrane protein kinase. Cell 73: 1197-1206.

Fassler, J.S., Gray, W., and Lee, J.P., Yu, G.Y., and Gingerich, G. (1991) The Saccharomyces cerevisiae SPT14 gene is essential for normal expression of the yeast transposon, Ty, as well as for expression of the HIS4 gene and several genes in the mating pathway. Mol Gen Genet 230: 310320.

Gietz, R.D., and Sugino, A. (1988) New yeast-Escherichia coli shuttle vectors constructed with in vitro mutagenized yeast genes lacking six-base pair restriction sites. Gene 74: 527-534.

Goldstein, A.L., and McCusker, J.H. (1999) Three new dominant drug resistance cassettes for gene disruption in Saccharomyces cerevisiae. Yeast 15: 1541-1553.

Han, M., and Grunstein, M. (1988) Nucleosome loss activates yeast downstream promoters in vivo. Cell 55: 11371145.

Han, M., Kim, U.J., Kayne, P., and Grunstein, M. (1988) Depletion of histone $\mathrm{H} 4$ and nucleosomes activates the $\mathrm{PHO5}$ gene in Saccharomyces cerevisiae. EMBO $J$ 7: 2221-2228.

Hanes, S.D., and Brent, R. (1989) DNA specificity of the Bicoid activator protein is determined by homeodomain recognition helix residue 9. Cell 57: 1275-1283.

Haze, K., Yoshida, H., Yanagi, H., Yura, T., and Mori, K. (1999) Mammalian transcription factor ATF6 is synthesized as a transmembrane protein and activated by proteolysis in response to endoplasmic reticulum stress. Mol Biol Cell 10: 3787-3799.

Howard, S.C., Chang, Y.-W., Budovskaya, Y.V., and Herman, P.K. (2001) The Ras/PKA signaling pathway of Saccharomyces cerevisiae exhibits a functional interaction with the Sin $4 p$ complex of the RNA polymerase II holoenzyme. Genetics 159: 77-89.

Howard, S.C., Budoskaya, Y.V., Chang, Y.-W., and Herman, P.K. (2002) The C-terminal domain of the largest subunit of RNA polymerase II is required for stationary phase entry and functionally interacts with the Ras/PKA signaling pathway. J Biol Chem 277: 19488-19497.

Hubbard, S.C., and Ivatt, R.J. (1981) Synthesis and processing of asparagine-linked oligosaccharides. Annu Rev Biochem 50: 555-583.

Jiang, Y.W., and Stillman, D.J. (1992) Involvement of the SIN4 global transcriptional regulator in the chromatin structure of Saccharomyces cerevisiae. Mol Cell Biol 12: 45034514.

Kim, S., Cabane, K., Hampsey, M., and Reinberg, D. (2000) Genetic analysis of the Ydr1-Bur6 repressor complex reveals an intricate balance among transcriptional regulatory proteins in yeast. Mol Cell Biol 20: 2455-2465.

Kohalmi, S.E., and Kunz, R.A. (1988) Role of neighbouring bases and assessment of strand specificity in ethylmethanesulphonate and $N$-methyl- $N$-nitro- $N$-nitrosoguanidine mutagenesis in the SUP4-o gene of Saccharomyces cerevisiae. J Mol Biol 204: 561-568.

Kohno, K., Normington, K., Sambrook, J., Gething, M.-J., and Mori, K. (1993) The promoter of the yeast KAR2 (BiP) gene contains a regulatory domain that responds to the presence of unfolded proteins in the endoplasmic reticulum. Mol Cell Biol 13: 877-890.

Kuchin, S., and Carlson, M. (1998) Functional relationships of Srb10-Srb11 kinase, carboxy-terminal domain kinase CTDK-I and transcriptional corepressor Ssn6-Tup1. Mol Cell Biol 18: 1163-1171.

Kuchin, S., Treich, I., and Carlson, M. (2000) A regulatory shortcut between the Snf1 protein kinase and RNA polymerase II holoenzyme. Proc Natl Acad Sci USA 97: 79167920.

Lawrence, C.W. (1991) Classical mutagenesis techniques. In Guide to Yeast Genetics and Molecular Biology: Methods in Enzymology, Vol. 194. Guthrie, C., and Fink, G.R. (eds). San Diego: Academic Press, pp. 273-281.

Liu, C.Y., Schröder, M., and Kaufman, R.J. (2000) Ligandindependent dimerization activates the stress response kinases IRE1 and PERK in the lumen of the endoplasmic reticulum. J Biol Chem 275: 24881-24885.

Mizuno, T., and Harashima, S. (2000) Activation of basal transcription by a mutation in SIN4, a yeast global repressor, occurs through a mechanism different from activatormediated transcriptional enhancement. Mol Gen Genet 263: 48-59.

Mori, K., Sant, A., Kohno, K., Normington, K., Gething, M.-J., and Sambrook, J.F. (1992) A 22 bp cis-acting element is necessary and sufficient for the induction of the yeast KAR2 (BiP) gene by unfolded proteins. EMBO J 11: 2583-2593.

Mori, K., Ma, W., Gething, M.-J., and Sambrook, J. (1993) A transmembrane protein with a cdc $2^{+} / C D C 28$-related kinase activity is required for signaling from the ER to the nucleus. Cell 74: 743-756.

Mori, K., Ogawa, N., Kawahara, T., Yanagi, H., and Yura, T. (1998) Palindrome with spacer of one nucleotide is characteristic of the cis-acting unfolded protein response ele- 
ment in Saccharomyces cerevisiae. J Biol Chem 273: 9912-9920.

Mori, K., Ogawa, N., Kawahara, T., Yanagi, H., and Yura, T. (2000) mRNA splicing-mediated C-terminal replacement of transcription factor Hac1p is required for efficient activation of the unfolded protein response. Proc Natl Acad Sci USA 97: 4660-4665.

Nojima, H., Leem, S.-H., Araki, H., Sakai, A., Nakashima, N., Kanaoka, Y., and Ono, Y. (1994) Hac1: a novel yeast bZIP protein binding to the CRE motif is a multicopy suppressor for cdc10 mutant of Schizosaccharomyces pombe. Nucleic Acids Res 22: 5279-5288.

Ye, J., Rawson, R.B., Komuro, R., Chen, X., Dave, U.P., Prywes, R., et al. (2000) ER stress induces cleavage of membrane-bound ATF6 by the same proteases that process SREBP2. Mol Cell 6: 1355-1364.

Rose, M.D., and Broach, J.R. (1991) Cloning genes by complementation in yeast. In Guide to Yeast Genetics and Molecular Biology: Methods in Enzymology, Vol. 194. Guthrie, C., and Fink, G.R. (eds). San Diego: Academic Press, pp. 195-230.

Rose, M.D., Novick, P., Thomas, J.H., Botstein, D., and Fink, G.R. (1987) A Saccharomyces cerevisiae genomic plasmid bank based on a centromere-containing shuttle vector. Gene 60: 237-243.

Scheuner, D., Song, B., McEwen, E., Liu, C., Laybutt, R., Gillespie, P., et al. (2001) Translational control is required for the unfolded protein response and in vivo glucose homeostasis. Mol Cell 7: 1165-1176.

Schröder, M., and Friedl, P. (1997) Overexpression of recombinant human antithrombin III in Chinese hamster ovary cells results in malformation and decreased secretion of the recombinant protein. Biotechnol Bioeng 53: 547-559.

Schröder, M., Chang, J.S., and Kaufman, R.J. (2000) The unfolded protein response represses nitrogen-starvation induced developmental differentiation in yeast. Genes Dev 14: 2962-2975.

Schwarz, R.T., Schmidt, M.F.G., and Datema, R. (1979) Inhibition of glycosylation of viral glycoproteins. Biochem Soc Trans 7: 322-326.

Seidman, C.E., Struhl, K., Sheen, J., and Jessen, T. (2000) Introduction of plasmid DNA into cells. In Current Protocols in Molecular Biology. Ausubel, F.M., Brent, R., Kingston, R.E., Moore, D.D., Seidman, J.G., Smith, J.A., and Struhl, K. (eds). New York: John Wiley \& Sons, pp. 1.8.11.8.10.

Sherman, F. (1991) Getting started with yeast. In Guide to Yeast Genetics and Molecular Biology: Methods in Enzymology, vol. 194. Guthrie, C., and Fink, G.R. (eds). San Diego: Academic Press, pp. 3-21.

Shamu, C.E., and Walter, P. (1996) Oligomerization and phosphorylation of the Ire1p kinase during intracellular signaling from the endoplasmic reticulum to the nucleus. EMBO J 15: 3028-3039.

Shen, X., Ellis, R.E., Lee, K., Liu, C.-Y., Yang, K., Solomon,
A., et al. (2001) Complementary signaling pathways regulate the unfolded protein response and are required for $\mathrm{C}$. elegans development. Cell 107: 893-903.

Shimizu, M., Li, W., Shindo, H., and Mitchell, A.P. (1997) Transcriptional repression at a distance through exclusion of activator binding in vivo. Proc Natl Acad Sci USA 94: 790-795.

Sidrauski, C., and Walter, P. (1997) The transmembrane kinase Ire1p is a site-specific endonuclease that initiates mRNA splicing in the unfolded protein response. Cell 90: 1031-1039.

Sidrauski, C., Cox, J.S., and Walter, P. (1996) tRNA ligase is required for regulated mRNA splicing in the unfolded protein response. Cell 87: 405-413.

Sikorski, R.S., and Hieter, P. (1989) A system of shuttle vectors and yeast host strains designed for efficient manipulation of DNA in Saccharomyces cerevisiae. Genetics 122: 19-27.

Song, W., and Carlson, M. (1998) Srb/mediator proteins interact functionally and physically with transcriptional repressor Sfl1. EMBO J 17: 5757-5765.

Strathern, J.N., and Higgins, D.R. (1991) Recovery of plasmids from yeast into Escherichia coli: Shuttle vectors. In Guide to Yeast Genetics and Molecular Biology: Methods in Enzymology, Vol. 194. Guthrie, C., and Fink, G.R. (eds). San Diego: Academic Press, pp. 319-329.

Travers, K.J., Patil, C.K., Wodicka, L., Lockhart, D.J., Weissman, J.S., and Walter, P. (2000) Functional and genomic analyses reveal an essential coordination between the unfolded protein response and ER-associated degradation. Cell 101: 249-258.

Wach, A., Brachat, A., Pöhlmann, R., and Philippsen, P. (1994) New heterologous modules for classical of PCRbased gene disruptions in Saccharomyces cerevisiae. Yeast 10: 1793-1808.

Wahi, M., and Johnson, A.D. (1995) Identification of genes required for $\alpha 2$ repression in Saccharomyces cerevisiae. Genetics 140: 821-831.

Wang, Y., Shen, J., Arenzana, N., Tirasophon, W., Kaufman, R.J., and Prywes, R. (2000) Activation of ATF6 and an ATF6 DNA binding site by the endoplasmic reticulum stress response. J Biol Chem 275: 27013-27020.

Welihinda, A.A., Tirasophon, W., Green, S.R., and Kaufman, R.J. (1998) Protein serine/threonine phosphatase Ptc2p negatively regulates the unfolded-protein response by dephosphorylating Ire1p kinase. Mol Cell Biol 18: 19671977.

Yoshida, H., Matsui, T., Yamamoto, A., Okada, T., and Mori, K. (2001) XBP1 mRNA is induced by ATF6 and spliced by IRE1 in response to ER stress to produce a highly active transcription factor. Cell 107: 881-891.

Zaman, Z., Ansari, A.Z., Koh, S.S., Young, R., and Ptashne, M. (2001) Interaction of a transcriptional repressor with the RNA polymerase II holoenzyme plays a crucial role in repression. Proc Natl Acad Sci USA 98: 2550-2554. 